Research article

\title{
Insights to bioprocess and treatment competence of urban wetlands
}

\author{
Durga Madhab Mahapatra ${ }^{a, b, c}$, N.V. Joshi ${ }^{\text {b }}$, T.V. Ramachandra ${ }^{\text {b, c, d, * }}$ \\ ${ }^{a}$ Biological and Ecological Engineering (BEE), Oregon State University, Corvallis, OR, United States \\ ${ }^{\mathrm{b}}$ Energy and Wetlands Research Group (EWRG), Center for Ecological Sciences (CES), Indian Institute of Science, Bangalore, India \\ ${ }^{c}$ Centre for Sustainable Technologies (CST), Indian Institute of Science (IISc), Bangalore, India \\ d Centre for Infrastructure, Sustainable Transportation and Urban Planning (CiSTUP), IISc, Bangalore, India
}

\section{A R T I C L E I N F O}

\section{Article history:}

Received 31 May 2017

Received in revised form

16 October 2017

Accepted 23 October 2017

Available online 26 November 2017

\section{Keywords:}

Water quality

Urban

Wetlands

Lakes

Algae

Flow cytometry

\begin{abstract}
A B S T R A C T
Wetlands play a major role in the recharge of groundwater resources, maintenance of water quality (remediation), moderate microclimate while supporting local livelihood through provision of fish, fodder, etc. The present study aims to investigate algal-bacterial consortium as a function of residence time with the water quality dynamics in two major wetlands in Bangalore city, India. Over thirty-two genera of algae were recorded with more than 40 species in the lakes and two dominant bacterial assemblages. The higher Ammonium-N content favoured the growth of these members. Significant correlation was observed between the nutrient concentrations and the community structure at the inflows and the outflows. The algal community showed negative correlation to filterable COD and high nutrients levels while bacterial abundance was observed under high loadings. The green algae Chlorophyceae (Chlorella blooms), which are indicators of nutrient enrichment were observed predominantly, that needs an immediate attention. Higher overall treatment efficiency was observed in terms of CNP removal during the Pre-monsoon season attributed to absence of macrophytes cover and rapid growth of algal assemblage's due to higher temperature regimes with adequate solar insolation.
\end{abstract}

๑) 2017 Elsevier Ltd. All rights reserved.

\section{Introduction}

Unplanned rapid urbanization due to globalisation and subsequent push for the industry-economic development in nineties have resulted in the increased stress on natural resources evident from the significant deterioration of urban wetlands/lakes in terms of quality and quantity, aquatic biodiversity, eco-aquatic processes, land use land cover (LULC) and micro-hydrological regimes (Ramachandra et al., 2006; Ramachandra, 2008; Martinuzzi et al., 2014). Untreated or partially treated industrial and domestic wastewater generated in urban locality taking advantage of the existing natural drains in the system of interconnected lakes. Sustained inflow of untreated sewage, though aided in maintaining the water levels, but has contributed to the nutrient enrichment rendering lakes vulnerable to blooms, frothing, foul odour with influx of wide spectrum of organics and inorganics, heavy metals (Timothy, 2000) and xenobiotics. The prime source of pollution is

\footnotetext{
* Corresponding author. Energy \& Wetlands Research Group, CES TE15, Centre for Ecological Sciences, Indian Institute of Science, Bangalore, 560019, India. E-mail address: tvr@iisc.ac.in (T.V. Ramachandra).

URL: http://ces.iisc.ernet.in/energy
}

untreated domestic and industrial wastewater in the urban catchment (Ramachandra et al., 2006, 2013; 2017).

The interaction among the various physico-chemical components of abiotic environment has profound impact on the local microflora and on the primary productivity and treatment capability (Carta-Escobar et al., 2004) of urban wetlands. Bacteria (Paerl et al., 2003), algae (Mahapatra et al., 2011a) and the aquatic plants (Mahapatra et al., 2011b,c) play a major role in remediation and aid as bio-indicators indicating the health of wetlands. The physicochemical environment together with the abundance of the biological organisms decides the utility of the wetlands (lakes), whether it is fit for recreational, irrigational or potable purposes (Figueiredo et al., 2010). The presence of organics in water, due to inflow of untreated sewage and other high impact industrial toxicants alters the biotic community composition as the micro and macrophytes are sensitive to nutrients loads, various pollutants and alterations of the microenvironment. The changes in the community structure also affect the treatment potential (Kayombo et al., 2002; Tarlan et al., 2002; Kirkwood et al., 2003). The most tolerant and resistant micro flora constitute community assemblage, in urban wetlands with high influx of untreated domestic wastewaters loads (Timothy, 2000; Mahapatra et al., 2011a)/ 
treatment plant effluents (Mahapatra et al., 2013a,b; Mahapatra et al., 2014; Ramachandra et al., 2015), landfill leachate (Naveen et al., 2017) and industrial effluents (Veeresh et al., 2009; Ramachandra et al., 2012).

The changes in the microbial community structure have altered the metabolic flux flow, which alter the integrity of aquatic ecosystem impairing its functions. This necessitates understanding of all major ecological entities and their dynamics with the nutrient influx, mobilization and accumulations to address sustainability of the ecological processes. Advanced metagenomic techniques are presently being used for a detailed characterization of the eukaryotic and the prokaryotic community structures (Zarraonaindia et al. 2013). Such analyses provide insight to the bioprocesses that help in identifying the pollution pattern and impacts (Singh et al., 2009). However, these techniques are expensive and do not reveal either causal factors or the pollution status. The physico-chemical parameters and the microflora community structure form a complex data structure, and require multivariate analysis and data treatment for the evaluation of water quality and the impact on micro flora (Bernal et al., 2008) with changes in the spatiotemporal patterns. Evaluation of the ecological structure and status of wetlands, pattern recognitions for variability in species abundance and their turnover, and development of an easy assessment tool for management have been done for Dianchi Lake (Yang et al., 2010) and Baiyangdian Lake (Zhao et al., 2012) in China; Navisha Lake, Kenya, (Ndungu et al., 2014), Curtin Lake in Malaysia (Prasanna et al., 2012). The objective of this study is to understand the linkages of the seasonal dynamics in physico-chemical and microflora bioprocesses in two major lakes in Bangalore region and evaluate the treatment competency of wastewater fed lakes.

\section{Material and methods}

\subsection{Study area and its characteristics}

The study was undertaken in two major wetlands in the Bangalore city namely Bellandur and Varthur wetlands (Fig. 1). Bangalore has the distinction of having interconnected wetlands due to undulating terrains with three major watersheds (Ramachandra et al., 2016). Bellandur Lake is the largest Lake in the Bangalore city and spreads across an area of 365 ha (mean depth $1.8 \mathrm{~m}$ ). It is situated $5 \mathrm{~km}$ upstream of Varthur Lake. These lakes receive $\sim 500$ million litres per day (MLD) of untreated or partially treated wastewater, which include municipal wastewater from i) residential areas near the old Bangalore Airport, and ii) regions around Challaghata and Koramangla that directly flows to these lakes through connected drains. Varthur wetlands/lake is also situated in the south of Bangalore, covers a water-spread area of 220 ha (mean depth $1.1 \mathrm{~m}$ ) built for catering the decentralised demand of water for domestic and agricultural uses.

The Varthur-Bellandur Lake catchment has seen large-scale land use changes after 2000, consequent to the rapid unplanned urbanization process in the region. The characteristics of both the water bodies are provided in Table 1 .

\subsection{Water sampling and analysis}

Water samples from inlets, middle and outlets were collected across different seasons to evaluate the influent and the effluent water quality. These lakes had a varying extent of floating macrophytes during different seasons, which impeded the use of boats for sampling. Only samples closer to the shore could be reliably sampled at specific times of a day as the wind induced drift of floating macrophytes on the lake made time-specific sampling of all the points unfeasible.
The average annual precipitation of Bangalore is about 700-850 $\mathrm{mm}$ and temperatures vary from $14{ }^{\circ} \mathrm{C}$ (December to January) to $33^{\circ} \mathrm{C}$ (maximum during March to May). There are two rainy periods, i.e. south-west monsoon (June to September) and north-east monsoon (November to December) (Mahapatra et al., 2011a; Ramachandra et al., 2016). During these periods, fresh water enters the lake as runoff. Water samples were collected regularly every month from five predetermined sampling points (locations were recorded using a hand-held pre-calibrated GPS (Global Positioning System, Garmin 48 and 60) to represent inlets, outlets and midpoints (Fig. 1). Physico-chemical parameters - pH, air temperature, water temperature, TDS, EC, turbidity, transparency and DO were measured at site following the standard protocol. Water samples were collected in 1 litre disinfected containers for estimation of chemical parameters in the laboratory (APHA AWWA WEF, 1998). Table S1 in the Supplementary material lists parameters and method adopted for analysis.

\subsubsection{Water and key biota analysis}

Water samples were also collected seasonally for 15 months from inflows, middle reaches and outflows of Bellandur and Varthur Lakes (Fig. 1) to examine the influent and the effluent water quality together with capturing the water quality in the middle reaches. Nutrient removal was calculated as per equation (1), for COD, BOD, N-species and P-species to assess the treatment efficiencies (in \%).

$\%$ Removal $=\left\{\frac{\left(C_{i n}-C_{\text {eff }}\right)}{C_{i n}}\right\} \times 100$

where, Cin is the concentration of the influent, Ceff is concentration of the effluent.

\subsubsection{Bacterial, algal and macrophyte analysis}

$100 \mathrm{ml}$ of sample were collected from the select locations and were fixed with 70\% alcohol. Species were identified using light microscope (Lawrence and Mayo) at $40 \times$ with the help of morphological keys as per literatures (Prescott, 1954, 1962; Desikachary, 1959). The algal members were enumerated by following earlier protocols (Mahapatra et al., 2013a,b). The bacterial count and morphology assessments were done through flow cytometry (FACS Caliber) following Gasol and Giorgio (2000) and with Electron Microscopy. These results were compared with the results of light microscope observations. Flow cytometry technique was adopted for rapid enumeration apart from exploration of different bacteria population, which is superior to plating as it is prone to contamination. Bacterio-plankton population was analysed by first filtering the samples with $2.5 \mu \mathrm{m}$ sieve and then were analysed by the FSC (forward scatter) plots. Macrophytes were collected from the sampling locations and were identified following standard keys for freshwater plants in India by CDK Cook, 1996.

\subsubsection{Bacterial analysis through scanning electron microscopy} (SEM) and flow cytometry (FC)

At a stable $\mathrm{pH}$, the cells were fixed in $2.5 \%$ glutaraldehyde. Samples were dried after dehydration through a series of ethanol in buffer of increasing strength $(30,50,70,80,90$, and absolute 10 min each). Specimen were mounted, gold sputtered and examined through electron microscopy following earlier protocols (Mahapatra et al., 2014). $1.5 \mathrm{ml}$ of 2 micron filtered samples (wastewater/sludge supernatant) were fixed with $1 \%$ paraformaldehyde $+0.05 \%$ glutaraldehyde (final), allowed in the dark, deep frozen in liquid nitrogen for $10 \mathrm{~min}$ to fix and then 


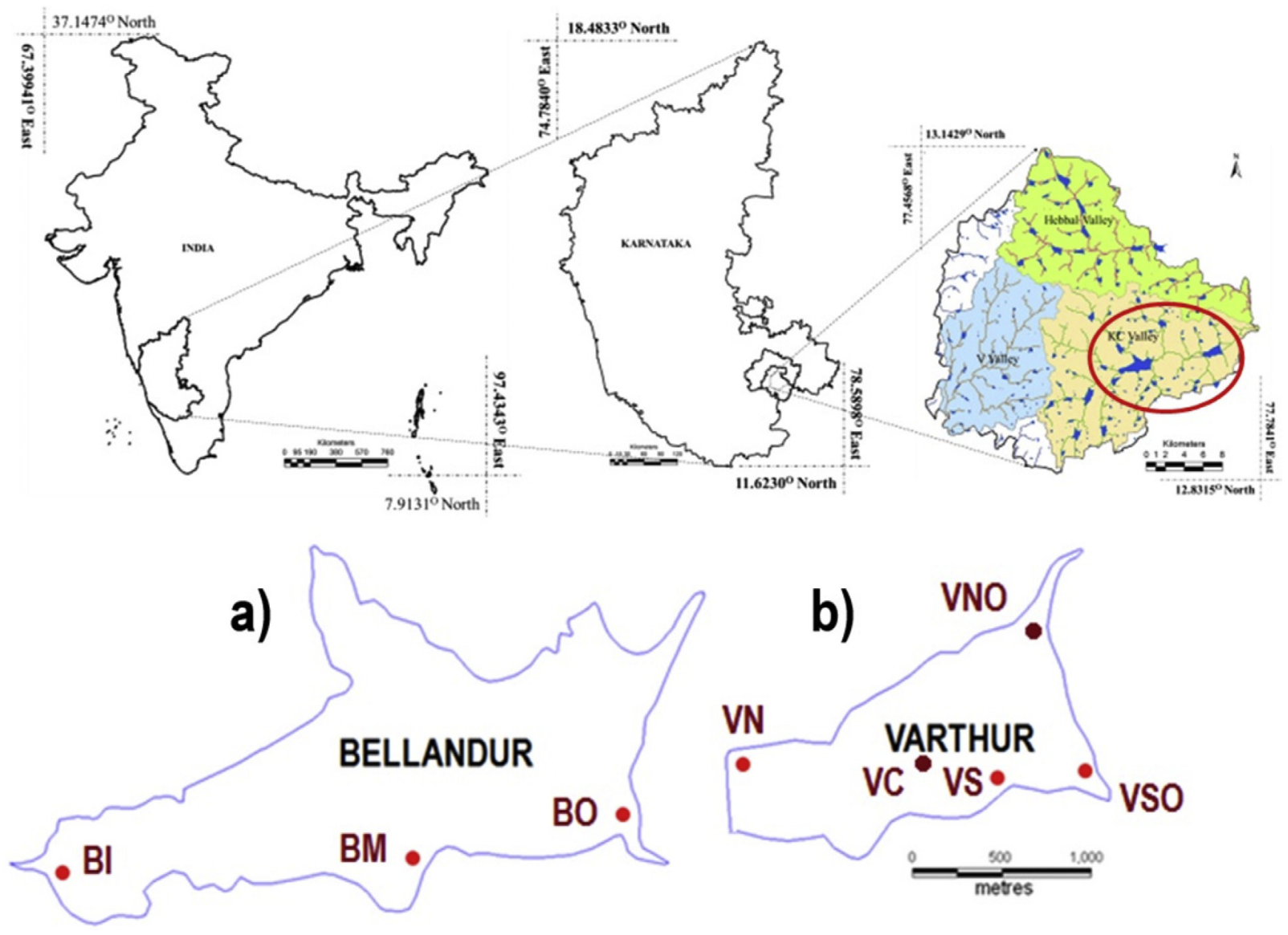

Fig. 1. Study Area - Greater Bangalore; Two large lakes of Bangalore a) Bellandur Lake and b) Varthur Lake. Sampling period (July-June, one year) - Sampling locations in Bellandur Lake: BI (Bellandur Inlet), BM (Bellandur Middle) and BO (Bellandur Outlet) along with Inlet (VN), Middle (VS) and Oulet regions (VSO) of Varthur Lake.

Table 1

Characteristics of the study area.

\begin{tabular}{lll}
\hline Characteristics & Bellandur Lake & Varthur Lake \\
\hline Location & SE of Bangalore & SE of Bangalore \\
Coordinates & $12.943917^{\circ}-12.927959^{\circ} \mathrm{N}$ & $12.956683^{\circ}-12.941499^{\circ} \mathrm{N}$ \\
& $77.638344^{\circ}-77.680167^{\circ} \mathrm{E}$ & $77.745378^{\circ}-77.72805^{\circ} \mathrm{E}$ \\
Primary inflows & Sewage from Bangalore & Bellandur \\
Primary outflows & Varthur Lake & To river Pennar \\
Catchment area (sq km) & 148 & 166 \\
Max. length $(\mathrm{km})$ & 3.6 & 2 \\
Max. width (km) & 1.4 & 1.1 \\
Surface area (sq km) & 3.6 & 2.2 \\
Mean depth (m) & 2.1 & 1.1 \\
Surface elevation (m) & 921 & 919 \\
Water colour & Greenish & Greenish (intense) \\
Odour & Yes & Yes \\
Macrophyte cover & Eicchornia, & Eicchornia, Alternanthera \\
& Alternanthera, Cyperus & Typha, Lemna \\
\hline
\end{tabular}

stored frozen at $-70{ }^{\circ} \mathrm{C}$ for estimating the bacterial abundance. FACS Caliber of Becton and Dickinson with a laser emitting at $488 \mathrm{~nm}$, samples were treated at low speed (approx.18 $\mu \mathrm{l} / \mathrm{min}$ ) with acquisition of data in log mode until 10000 events. Samples were diluted when the sample acquisition rate is higher than 800 cells/s. Usually $10 \mu \mathrm{l}$ per $200-\mu \mathrm{l}$ sample is added of a $10^{6} / \mathrm{ml}$ solution of yellow-green $0.92 \mu \mathrm{m}$ Polysciences latex beads as an internal standard. Bacteria were detected by their signature in a plot of Side scatter (SSC) vs. Forward scatter (FSC). Adjustments were made in the settings so that the beads fall in channels $\sim 10^{3}$ for SSC and FL1/
FSC as per standard protocol (Giorgio et al., 1996; Gasol and Giorgio, 2000).

\subsection{Data analysis}

Relationship between changes in physico-chemical variables and biological variables (relative abundance of algal classes and algal/bacterial abundance) was assessed through the computation of nonparametric Spearman's rank correlation coefficient ( $r$ ). Multivariate analysis - canonical correspondence analysis (CCA) 
was carried out to understand interplays between biological communities with varying physicochemical variables and seasons and to know relationships among them (Martin-Cereceda et al., 2001; Iscen et al., 2008). Higher variability in abundance was handled through $\log _{10}$ transformation of the values. The spatial similarity and patterns across sites was assessed through Bray - Curtis cluster analysis (CA). An open source statistical package PAST 2.14 was used to implement statistical analyses.

\section{Results and discussion}

3.1. Role of microphyte (algae and bacteria) and macrophyte abundance and distribution in the nutrient dynamics

The physico-chemical alterations occurring spatio-temporally in lakes influence the incidence and activities of algal-bacterial systems in aquatic ecosystems, which has been observed in the present study. Urban lakes with the sustained inflow of untreated wastewater behaves as wastewater lagoons, with an initial anaerobic phase followed by an aerobic process (algal-bacterial symbiosis) where, the macromolecular complex biomolecules as polysaccharides, protein and lipids are first degraded by bacteria (Roche, 1998; Carta-Escobar et al., 2004). Subsequently, the algal systems are involved in key processes of i) reducing carbon (Mahapatra et al., 2013a) ii) inorganic nutrient ( $\mathrm{N}$ and $\mathrm{P}$ ) uptake (Mahapatra et al., 2013b) ii) storage of lipids (Ramachandra et al., 2009; Mahapatra and Ramachandra, 2013), proteins (Mahapatra et al., 2016) and carbohydrates (Ramachandra and Mahapatra, 2015) iv) pathogen removal by creating a high $\mathrm{pH}$ environment through algal photosynthesis (Mahapatra, 2015) and v) maintain the aerobic environment for the functioning of the treatment processes (Hosetti and Frost, 1998; Kirkwood et al., 2003; Chanakya et al., 2012, 2013; Mahapatra et al., 2013b). Higher species diversity, seasonal variations and species succession were noticed as these characteristics are a function of organic load, retention time, photoperiod, light intensities and predation by zooplanktons (Tharavathy and Hosetti, 2003; Ahmadi et al., 2005). The treatment levels and status of such kind of wastewater fed system have been assessed through investigations of the type of algae, their densities in terms of abundance; biomass and community structure (Sukias et al., 2001).

\subsection{Seasonal variability's in nutrients and other parameters}

At each sampling locations (Fig. 1), multiple samples were collected. Physico-chemical parameters were estimated for each sample and Tables 2 and 3 list season-wise water quality parameters. Monsoon corresponds to June to November months of Southwest and North-east monsoon period. pH values ranged from 7.4 8.2 in Bellandur Lake and the highest $\mathrm{pH}$ was observed in the outlet reaches during the pre-monsoon period (Table 2). Varthur Lake recorded the maximum $\mathrm{pH}$ of 7.9 at the inflows during the premonsoon period and $\mathrm{pH}$ range from 7.5 to 7.9 (Table 3). Higher values of EC were observed during the pre-monsoon periods in both Bellandur and Varthur Lakes inflows and outflows and lowest were observed during monsoon.

Highest turbidity values (386 NTU) were recorded in the Bellandur lake inflows during the post-monsoon, and the minimum values were recorded during the monsoon (71-79 NTU). Varthur Lake recorded maximum turbidity (325 NTU) values in the inflows during the pre-monsoon period and lowest values during the postmonsoon period. Complete anoxic conditions were observed in Bellandur and Varthur Lakes owing to macrophyte cover and higher organic loads. Higher COD and BOD values were also recorded during the pre-monsoon period in both lakes.
Table 2

Seasonal variations in treatment parameters in Bellandur Lake.

\begin{tabular}{|c|c|c|c|c|c|c|}
\hline \multirow[t]{3}{*}{ Parameters } & \multicolumn{6}{|c|}{ Bellandur Lake } \\
\hline & \multicolumn{2}{|c|}{ Pre-monsoon } & \multicolumn{2}{|c|}{ Monsoon } & \multicolumn{2}{|c|}{$\begin{array}{l}\text { Post- } \\
\text { monsoon }\end{array}$} \\
\hline & Inlet & Outlet & Inlet & Outlet & Inlet & Outlet \\
\hline $\mathrm{pH}$ & 7.9 & 8.2 & 7.4 & 7.8 & 7.7 & 7.8 \\
\hline Temperature $\left({ }^{\circ} \mathrm{C}\right)$ & 27.8 & 27.3 & 24.1 & 23.7 & 24 & 21 \\
\hline Electrical Conductivity $(\mu \mathrm{S} / \mathrm{cm})$ & 1098 & 1057 & 661 & 735 & 980 & 1009 \\
\hline Total Dissolved Solids (mg/l) & 868 & 840 & 526 & 592 & 770 & 808 \\
\hline Turbidity (NTU) & 216. & 96.5 & 71.4 & 79.2 & 386 & 98.9 \\
\hline Dissolved Oxygen (mg/l) & 0.0 & 0.0 & 0.0 & 0.0 & 0.0 & 0.0 \\
\hline Free $\mathrm{CO}_{2}(\mathrm{mg} / \mathrm{l})$ & 69 & 21.84 & 48.4 & 61.6 & 64 & 120 \\
\hline $\mathrm{COD}(\mathrm{mg} / \mathrm{l})$ & 340 & 153 & 266 & 140 & 253 & 122 \\
\hline Filtrable COD (mg/l) & 182 & 102 & 123 & 93 & 133 & 88 \\
\hline BOD $(\mathrm{mg} / \mathrm{l})$ & 198 & 74 & 120 & 78 & 170 & 132 \\
\hline Nitrates (mg/l) & 0.05 & 0.04 & 0.76 & 1.63 & 0.98 & 0.67 \\
\hline Amm-N (mg/l) & 54 & 29 & 32 & 19 & 65 & 24 \\
\hline $\mathrm{TN}(\mathrm{mg} / \mathrm{l})$ & 62 & 44 & 64 & 31 & 69 & 27 \\
\hline Ortho-Phosphates (mg/l) & 2.10 & 1.8 & 3.28 & 3.36 & 2.97 & 3.76 \\
\hline $\mathrm{TP}(\mathrm{mg} / \mathrm{l})$ & 16 & 12 & 37 & 19 & 28 & 11 \\
\hline Alkalinity (mg/l) & 520 & 300 & 360 & 400 & 260 & 300 \\
\hline Total Hardness (mg/l) & 196 & 204 & 268 & 232 & 292 & 276 \\
\hline Chlorides (mg/l) & 84 & 73 & 82.36 & 85.2 & 86 & 93 \\
\hline Sodium (mg/l) & 54 & 43.82 & 39.7 & 40.4 & 68 & 62 \\
\hline Potassium (mg/l) & 10.4 & 9.72 & 9.1 & 10 & 9.8 & 11.2 \\
\hline ORP $(\mathrm{mV})$ & -180 & -150 & -96 & -165 & -245 & -220 \\
\hline
\end{tabular}

During the entire sampling period, low nitrification was observed as evident from the nitrate values ranging from 0.04 to $1.5 \mathrm{mg} / \mathrm{l}$ compared to Amm.-N that ranged from 14 to $65 \mathrm{mg} / \mathrm{l}$. Higher values of Amm.-N ( $30 \mathrm{mg} / \mathrm{l})$ were reported by the earlier studies (Chanakya and Sharatchandra, 2008). Nitrate and nitrite concentration constituted an insignificant portion of the dissolved nitrogen pool $(<2.0 \%)$. Higher Amm.-N were consistently observed in the inflow regions especially in Bellandur Lake during the post monsoon period indicating an inflow of already decomposing wastewater. TN values were higher during the post monsoon period at the inflows in Bellandur Lake and during the pre-monsoon periods in the inflows of Varthur Lake and are elucidated in Tables 2 and 3 respectively. Ortho phosphates levels ranged from 1.8 $3.76 \mathrm{mg} / \mathrm{l}$ in Bellandur Lake and $1.32-3.51 \mathrm{mg} / \mathrm{l}$ in Varthur Lake and were comparatively higher in the outlets owing to P re-suspension from anoxic bottom. However, TP values were higher in the inflows compared to the outflows and were ranging from 11 to $37 \mathrm{mg} / \mathrm{l}$ in Bellandur Lake and 9-19 mg/l in Varthur Lake.

\subsection{Treatment aspects of lakes}

These lakes have been functioning as lagoons or functionally comparable to stabilisation ponds with the thriving algal-bacterial communities that helps in maintaining the overall quality of the water. In the current study, a maximum removal of total COD ( $55 \%)$; filterable COD ( 44\%); Net COD (67.7\%) and BOD (62.5\%) was observed during the pre-monsoon season in Bellandur lake where as filterable COD and BOD removal was better during the post-monsoon period (Table 4 and Fig. S1, Supplementary material) attributable to rapid $C$ uptake and transformations at high temperature with higher insolation through the algal $C$ sequestration route. In the case of Varthur Lake, highest total COD removal (52\%) was recorded in monsoon period, where as maximum BOD ( 62\%); filterable COD (44\%) and Net COD (70\%) removal took place during the pre-monsoon period and the reasons are similar to the observations in Bellandur lake.

Highet TN removal was observed during post-monsoon period $(\sim 61 \%)$ in Bellandur Lake attributed to anoxic environments due to 
Table 3

Seasonal variations in treatment parameters in Varthur Lake.

\begin{tabular}{|c|c|c|c|c|c|c|}
\hline \multirow[t]{3}{*}{ Parameters } & \multicolumn{6}{|c|}{ Varthur Lake } \\
\hline & \multicolumn{2}{|c|}{ Pre-monsoon } & \multicolumn{2}{|c|}{ Monsoon } & \multicolumn{2}{|c|}{ Post-monsoon } \\
\hline & Inlet & Outlet & Inlet & Outlet & Inlet & Outlet \\
\hline $\mathrm{pH}$ & 7.6 & 7.76 & 7.85 & 7.53 & 7.9 & 7.5 \\
\hline Temperature $\left({ }^{\circ} \mathrm{C}\right)$ & 28.6 & 26 & 27.7 & 29.1 & 22 & 23 \\
\hline Electrical Conductivity $(\mu \mathrm{S} / \mathrm{cm})$ & 1420 & 1114 & 910 & 897 & 977 & 952 \\
\hline Total Dissolved Solids (mg/l) & 994 & 792 & 720 & 712 & 768 & 755 \\
\hline Turbidity (NTU) & 325 & 108 & 216 & 102 & 161 & 65 \\
\hline Dissolved Oxygen (mg/l) & 0.0 & 0.98 & 0.54 & 0.13 & 0.78 & 0.88 \\
\hline Free $\mathrm{CO}_{2}(\mathrm{mg} / \mathrm{l})$ & 55 & 12.4 & 40.2 & 21.8 & 14.96 & 8.8 \\
\hline $\operatorname{COD}(\mathrm{mg} / \mathrm{l})$ & 224 & 192 & 220 & 133 & 188 & 120 \\
\hline Filtrable COD (mg/l) & 146 & 102 & 113 & 86 & 146 & 93 \\
\hline BOD $(\mathrm{mg} / \mathrm{l})$ & 172 & 135 & 125 & 78 & 130.47 & 74.9 \\
\hline Nitrates $(\mathrm{mg} / \mathrm{l})$ & 0.26 & 0.38 & 1.39 & 1.43 & 0.36 & 0.6 \\
\hline Amm-N (mg/l) & 44 & 14 & 37.5 & 19 & 42 & 22 \\
\hline $\mathrm{TN}(\mathrm{mg} / \mathrm{l})$ & 49 & 21 & 39 & 22 & 47 & 23 \\
\hline Ortho-Phosphates (mg/l) & 2.66 & 3.51 & 1.72 & 3.04 & 1.32 & 1.72 \\
\hline $\mathrm{TP}(\mathrm{mg} / \mathrm{l})$ & 18 & 14 & 16.5 & 9 & 19 & 13.7 \\
\hline Alkalinity (mg/l) & 400 & 360 & 360 & 380 & 380 & 330 \\
\hline Total Hardness (mg/l) & 508 & 272 & 248 & 256 & 264 & 288 \\
\hline Chlorides (mg/l) & 446 & 149 & 85.2 & 90.88 & 99.4 & 85.2 \\
\hline Sodium $(\mathrm{mg} / \mathrm{l})$ & 1100 & 810 & 42.43 & 42.32 & 220 & 221 \\
\hline Potassium (mg/l) & 80 & 80 & 9.72 & 8.67 & 41.5 & 47 \\
\hline ORP $(\mathrm{mV})$ & -145 & -210 & -13 & -8 & -49 & -178 \\
\hline
\end{tabular}

Table 4

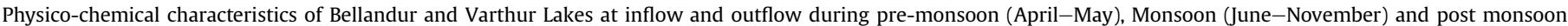
(December-March).

\begin{tabular}{|c|c|c|c|c|c|c|c|c|c|c|c|}
\hline \multirow[t]{2}{*}{ Water body } & \multirow[t]{2}{*}{ Period } & \multicolumn{10}{|c|}{ Percentage Removal } \\
\hline & & BOD & Total COD & Fil. COD & Net .COD (Tot-Filt) & $\mathrm{NO}_{3}-\mathrm{N}$ & $\mathrm{NH}_{4}-\mathrm{N}$ & TN & Ortho Phos. & $\mathrm{TP}$ & Bacterial cells \\
\hline \multirow[t]{3}{*}{ Bellandur } & Pre-Mon & 62.5 & 55 & 44 & 67.7 & 20 & 46.2 & 29.03 & 14.28 & 25 & 47.72 \\
\hline & Mon & 35 & 47.3 & 24.5 & 67.1 & -53.37 & 40.6 & 51.56 & -2.38 & 48.64 & 42.3 \\
\hline & Post-Mon & 22.4 & 51.7 & 34 & 71.7 & 31.63 & 63.07 & 60.86 & -21.01 & 60.71 & 25 \\
\hline \multirow[t]{3}{*}{ Varthur } & Pre-Mon & 21 & 14 & 30.1 & -15.3 & -31.5 & 68.18 & 57.14 & -24.21 & 22.22 & 57.14 \\
\hline & Mon & 37.6 & 39.5 & 23.9 & 56 & -2.79 & 49.33 & 43.58 & -43.42 & 45.45 & 31.57 \\
\hline & Post-Mon & 42.7 & 36.2 & 36.3 & 35.7 & -40 & 47.61 & 51.06 & -23.25 & 27.89 & 18.18 \\
\hline
\end{tabular}

large floating macrophytes debrii and floating islands comprising of macrophytes and resuspended sludge on the surface of the lake that drifts towards the outlets. Where as Varthur showed higher $\mathrm{N}$ removal during the pre-monsoon peroid $(\sim 57 \%)$ due to rapid algal uptake. Similarly, the Amm.-N removal was maximum during postmonsoon in Bellandur Lake ( 63\%) and pre-monsoon in Varthur Lake ( 68\%) attributable to Amm.-N loses due to increase $\mathrm{pH}$ consequent to algal photosynthesis at high light intensities (Weatherell et al., 2003). Higher TP removal was observed in case of Bellandur Lake ( $61 \%)$ during the post-monsoon peroid, but Varthur Lake showed higher TP removal $(45 \%)$ during monsoon. Samples at outlets were having higher values of orthophosphate than inflows attributable to higher mineralisation of organic phosphates as a function of residence time and due to resuspension of P from the lake bottom (Mahapatra et al., 2011a). A higher bacterial removal was observed during the pre-monsoon period in both the lakes due to higher solar illumination, high photosynthesis and consequent development of an increased $\mathrm{pH}$ value.

Enormous quantities of terrestrial nutrients gets immobilised in the physico-chemical environment and within the biological organisms present in these lakes. Approximately, 100 tonnes BOD/d, 31 tonnes $\mathrm{TN} / \mathrm{d}$ and 8 tonnes $\mathrm{TP} / \mathrm{d}$ of enters during pre-monsoon and 37 tonnes BOD/d, 22 tonnes TN/d and 6 tonnes TP/d of leaves from Bellandur Lake. In monsoon, $\sim 60$ tonnes BOD/d, 32 tonnes $\mathrm{TN} / \mathrm{d}$ and 18.5 tonnes $\mathrm{TP} / \mathrm{d}$ enters and 39 tonnes COD/d, 15.5 tonnes TN/d and 9.5 tonnes TP/d leaves from Bellandur lake and 85 tonnes BOD/d, 35 tonnes,TN/d and 14 tonnes TP/d entered during post-monsoon period while 66 tonnes BOD/d, 13.5 tonnes TN/d and 5.5 tonnes TP/d leaves the lake.

In the case of Varthur lake, 95 tonnes BOD/d, 27 tonnes TN/d and $\sim 10$ tonnesTP/d enters during the pre-monsoon period and $\sim 74$ tonnes BOD/d, 11.5 tonnesTN/d and 7.7 tonnes TP/d. During the monsoon peroid, $\sim 69$ tonnes BOD/d, 21.4 tonnes TN/d, $\sim 9$ tonnes/ $\mathrm{d}$ enters Varthur Lake and $\sim 43$ tonnes BOD/d, $\sim 12$ tonnes TN/d and $\sim 5$ tonnes TP/d leaves the system. $\sim 72$ tonnes BOD/d, $\sim 26$ tonnes $\mathrm{TN} / \mathrm{d}$ and $\sim 10$ tonnes TP/d enters Varthur lake during the postmonsoon peroid and $\sim 41$ tonnes BOD/d, $\sim 13$ tonnes TN/d and $\sim 7.6$ tonnes TP/d leaves the system daily. This provides vital insights for devising methods for recovering nutrients trapped in wastewater fed lakes and further engineer the system for optimal resource recovery and management.

\subsection{Algal community dynamics}

Over 32 genera of algae were recorded with more than 40 species. Chlorophyceae (13) dominated the algal community, followed by Bacillariophyceae (7), Cynaophyceae (6) and Euglenophyceae (4). Bellandur Lake inlets were dominated by the members of Cynaophyceae ( $45 \%$; Merismopedia sp. and Microcystis sp.) followed by Bacillariophyceae ( $35 \%$; Gomphonema parvalum) as these species can grow in low light conditions, during the pre-monsoon period. In the middle reaches, when the water is clearer and is 
free from organic suspenoides, the Chlorophycean members like Chlorella sp. dominated (75\%). However, Chlorophyceae (45\%) such as Chlorococcum sp. and Monoraphidium sp. dominated outlets. This indicated high photosynthesis by green algal members and requirement of light conditions for rapid photosynthesis (Weatherell et al., 2003). During the monsoon, the Bacillariophycean members dominated the inflows (78\%) and Chlorophycean members dominated the middle (78\%) and outlets (46\%). However, the post monsoon period recorded the highest abundance in the Chlorophycean members (Chlorella sp., Chlorococcum sp. and Monoraphidium sp.) members (62\% in middle; $88 \%$ in outlets). The inlet region was dominated by diatoms (72\%). Biofilms collected from the rock surface, plant surface and sediment layers showed dominance of filamentous algae (Oedogonium sp.) and diatom sp. (Gomphonema sp. and Navicula sp.). The distribution of the different members of phytoplankton at various sampling locations and seasons are presented in Fig. 2. Spatiotemporal variations in algal community's composition are dependent on the nutrient loads, physico-chemical environment and the micro-climatic variables. Solar insolation, precipitation and the wind velocity are crucial in partitioning of the nutrient regimes in the lakes spatially and vertically (Mahpatra et al., 2011b,c).

During pre-monsoon period, in Varthur Lake, diatoms ( $90 \%)$ dominated the inlet reaches followed by the Chlorophycean members in the middle (75\%) and the outfalls (45\%). However, during the monsoon period, the Chlorophycean members dominated both at inflow (32\%) and middle (66\%), while relative abundance of Cyanophyceae (47\%) were high near outlets. During the post monsoon, the Cholorophycean members dominated $(\sim 80 \%)$ in all these three locations. The results showed Scenedesmus sp., Anabaena sp. and Anacystis sp. were predominant near the shorelines while Chlorococcum sp. and Monoraphidium sp. $(<10 \mu \mathrm{m})$ were present during the monsoon season (80\%). Algal samples at inlets revealed predominance of Gomphonema sp. and Nitzschia sp. $(10-38 \mu \mathrm{m})$ i.e. diatoms during the monsoon, that are succeeded by euglenoides such as Euglena sp. and Phacus sp. $(>20 \mu \mathrm{m})$ in the pre monsoon period. Euglenoides are indicators of organic matter accumulation (Veeresh et al., 2009). During monsoon and post monsoon periods, the algal blooms at Bellandur Lake with higher abundance of Chlorophycean members act as inoculum for Varthur Lake.

Filamentous algae such as Phormidium sp., Oedogonium sp. and Oscillatoria sp. $(>30 \mu \mathrm{m})$ were present near the outlets of the Varthur Lake during monsoon season. Comparative analysis of algal populations in the biofilms revealed a noticeable difference in the community structures at various zones of the Lake. The epilithic (over solid surfaces) algal biofilm consisted of colonies of Stigeoclonium sp. Diatom species such as Gomphonema sp. and Nitzschia sp. were near the inlet regions and species of Chlorophyceae and Euglenophyceae were near outlet regions. These distributions are dependent on the environmental variables such as organic load, nutrients (N and P) and light availability (Mahapatra et al., 2011a). Season-wise investigations indicate that depending upon the wind direction, the extent of growth and movement of the macrophytes

\section{PRE-MONSOON}

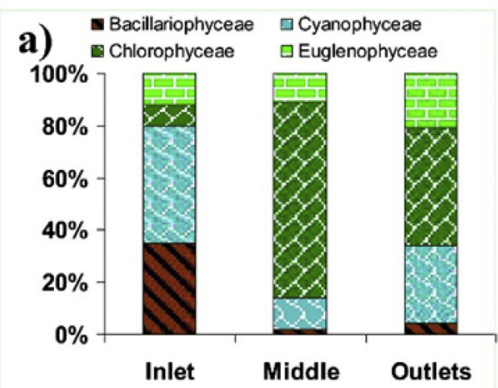

PRE-MONSOON

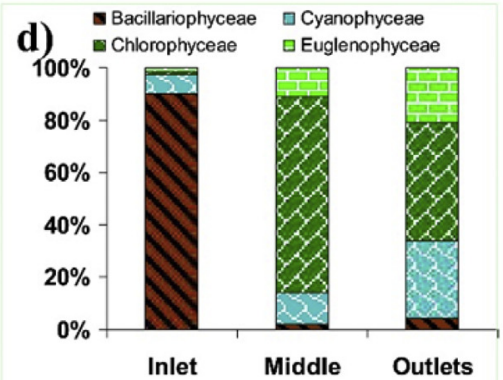

MONSOON

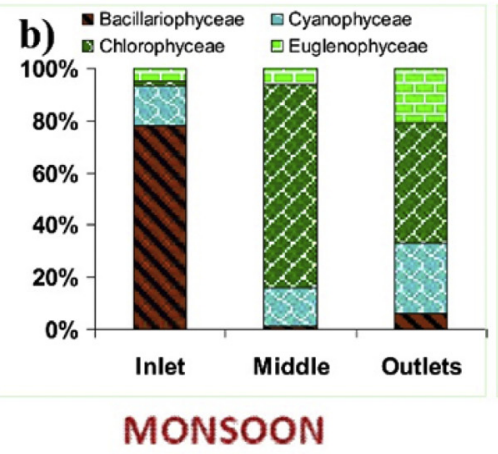

e)

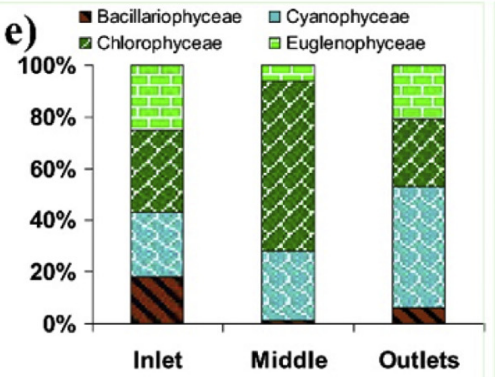

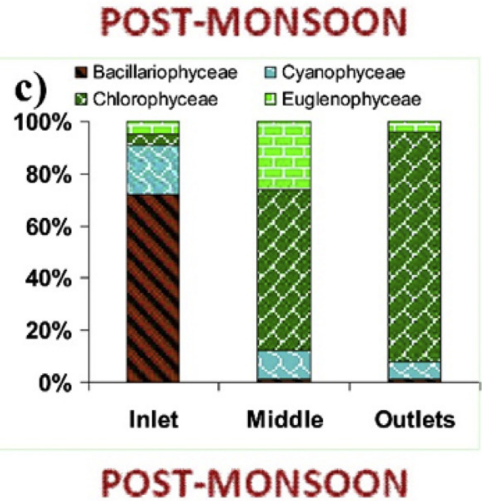

f) Bacillariophyceae $\square$ Cyanophyceae f) $\quad$ Chlorophyceae Euglenophyceae

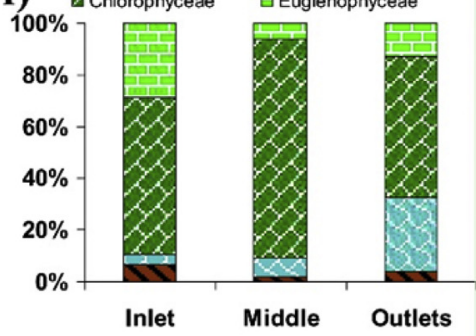

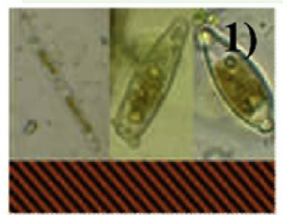

DIATOMS

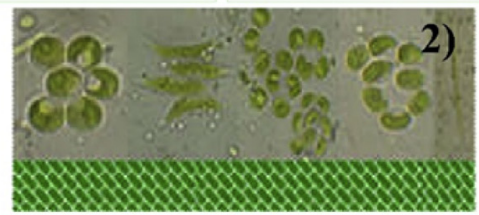

CHLOROPHYCEAE

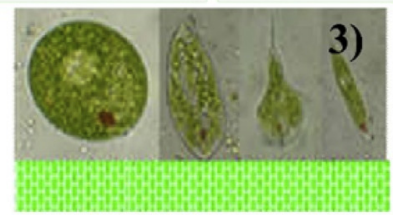

EUGLENOPHYCEAE

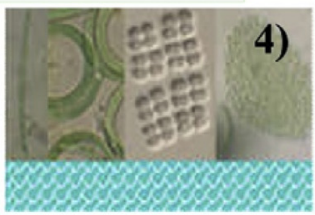

CYANOPHYCEAE

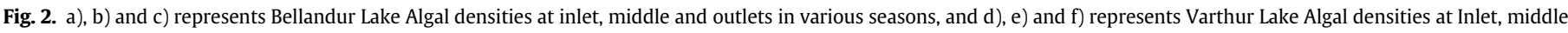

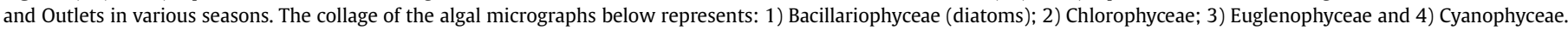


together with the nutrient influx, there is a periodic transition from the anaerobic-aerobic (in monsoon) to anaerobic (in summer) and aerobic-anaerobic system (winter/pre monsoon) in the lake. Table S2 (in the Supplementary material) lists the algal composition in studied lakes. Fig. 2 elucidates the season-wise transitions in the algal groups at the various sampling locations. The inflow regions of Varthur Lake suffered from higher anoxia during the pre-monsoon period with only Gomphonema sp. and Nitzschia sp. in shallow regions of the Lake. Inlet regions samples consistently showed a very low count of algal cells in the order of $10^{2}-10^{3}$ cells $/ \mathrm{ml}$. However, middle portion of the Lake showed an average cell count of $10^{6}$ $10^{7}$ cells $/ \mathrm{ml}$. The algal cell counts were lower of $10^{3}-10^{5}$ cells $/ \mathrm{ml}$ in outlet samples, owing to decreased algal abundance with poor interception of sunlight with dense macrophyte cover.

\subsection{Bacterio-plankton abundance and distribution}

Bacterial growth and community structure are the key biological parameters in wastewater systems. Until recently, bacterial biomass were analysed through either measurements of cell size, usually with image analysis (Blackburn et al., 1998) or epifluorescence microscopy DAPI/Acridine orange (Marie et al., 2017). These are time-consuming techniques and have constraints for continuous and large-scale estimation of bacterial abundance and biomass involving sampling and analysis that needs preservation (Gasol and Giorgio, 2000). In such systems, there is a need to differentially quantify the bacterial and algal biomass to understand the trophic contribution to the purification/treatment process. Flow cytometry (FC) techniques have been used in wastewater microorganisms monitoring especially bacteria for devising and evolving optimal treatment options for urban wastewater treatment. FC has its own advantages in terms of accuracy in cell counting, detecting capability of bacterial species and assessment of live and dead cells (Gasol and Giorgio, 2000). FC aids in the analyses of a large number of cells and recording variability's in cellular characteristics for each cell through several parameters (Shapiro, 2005). In FC, typically 200 to 2000 cells per second circulate (sheath fluid) across beam of a laser and captures the light scattered by each of the particles and the fluorescence emission at different wavelengths generated by the excitation of each particle. FC reduces the time needed for the determination of bacterial abundance, size and activity. In FC usage of various DNA based fluorescent stains, nucleic acid and immunofluorescence probes provide the technique with abilities to discriminate cells on the basis of extent and type of nucleic acids, respiratory enzyme and many other characteristics.

In flow cytometric analysis, three clusters of bacteria were distinguished through normal laser encounter (Fig. 3A-F) with respect to standard beads that were run for dimensionality (Fig. S2, supplementary material). These synthetic beads are used for identifying the potentials that act as markers for the dimension's/ size analysis of bacterio-planktons. Samples from the inlet regions (Fig. S3A) of Bellandur Lake showed a high cell density $\left(10^{7}\right.$ cells/ $\mathrm{ml}$ ). However, three different peaks were observed (Fig. S3B) in the middle zone. In samples collected from outlets, only one dominant type of bacteria (Fig. S3C) was observed.

Higher bacterial abundance was observed in the samples of Varthur Lake inlets (shown as single peak in Fig. S3D). Middle regions comprised of large groups of bacteria (Fig. S3E) as highlighted from two peaks indicated by the arrows. Outlet samples comprised mainly several medium sized bacteria represented by a prominent peak depicted in Fig. S3F. The corresponding flow-cytogram (SSC vs. FSC plots) for bacterial abundance and major groups are given in Fig. 3. The scanning electron microscope studies showed different types of bacteria i.e. coccoid, rod-shaped, and curved bacteria
(Fig. 4). Among them, the bacillus i.e. rod shaped bacteria were dominant and are indicator organism in wastewater fed systems.

\subsection{Changes in macrophyte communities and their distribution}

The most dominant macrophytes observed were the freefloating water hyacinth (Eichhornia crassipes) and the rooted alligator weed (Alternanthera philoxeroides). Water hyacinth was observed to bloom in the pre monsoon periods during the start of winter mostly in the month of January and then, they grow exponentially in the next three months (Jan-April) and cover almost $\sim 75 \%$ of the lake surface. In case of Bellandur Lake, the initial reaches are very shallow and are mostly occupied by the emergent Typha sp. At deeper regions, it is observed the predominance of free floating macrophytes, which are depicted in Fig. S4 (Supplementary material).

As the outlets of Bellandur are clogged with floating islands comprising of rooted macrophytes (water hyacinth is not removed from the Lake), and finally dies and settles down into the water after its growth and death (Battle et al., 2000). New macrophytes utilize this floating mass to form large islands. These floating islands mostly comprise of the lighter weight plants and matured sludge materials that accumulate and adhere to floating mass, because of sludge suspension that progressively compacts, dries and remain as huge floating masses that houses a wide range of macrophytes as Alternanthera philoxeroides, Colocassia, sedges as Cyperus spp. etc. Due to a permanent cover of the floating islands, lakes suffer anoxia due to which no DO was found in the water emerging from the outlets of Bellandur Lake (Mahaptra et al., $2011 \mathrm{~b}, \mathrm{c})$. These outlet regions therefore, have a highly reducing environment and are associated with odour of $\mathrm{H}_{2} \mathrm{~S}$.

However, in case of Varthur, the water hyacinth is periodically washed out from the system during monsoon due to high wind velocity and large quantum of water. Sometimes, the local people help in cleaning the clogged outlets to free up water movement during monsoon. Thus, Varthur Lake sheds most of macrophyte islands during monsoon and help to maintain open water surface. During summer, rapidly growing water hyacinth almost entirely covers the surface of the Lake during summer. Upon death, decay and compaction these floating macrophytes are then out-competed by Alternanthera sp. This species is a potential nutrient up-taker grows very rapidly after the death of the water hyacinth plants due to ageing and the weevil attacks. Species like Lemna and Pistia were mostly observed in the Lake edges and in the still and shallow regions. Typha sp. and sedges were observed in inflow regions of the water bodies. Fig. S4 (Supplementary material) shows the different macrophyte species found in these lakes based on nutrient affinity and prevailing environment. It was found that the presence of the floating macrophyte cover resulted in temporary anoxic zones and reduced algal growth, resulting in reduced conditions. Dense macrophyte cover in Varthur Lake has resulted in the absence of light penetration resulting in relatively low algal densities compared to the periods when the outlets are free of macrophytes with a reducing condition of low redox potential $(-145$ to $-210 \mathrm{mV}$ ).

\subsection{Multivariate analysis}

Algal abundance with other physico-chemical parameters linkages were assessed through multivariate statistics. Significant positive correlations $(\mathrm{r}=0.85 ; \mathrm{p}<0.01)$ were found between the biomass of Chlorophyceae members with total phosphates (TP). However, the other group of algae as Cyanophyceae were negatively correlated with TP $(r=-0.699 ; \mathrm{p}<0.05)$ which could be due to higher $\mathrm{P}$ accumulation capacity of cyanophytes that they use for 
$\mathbf{A}$
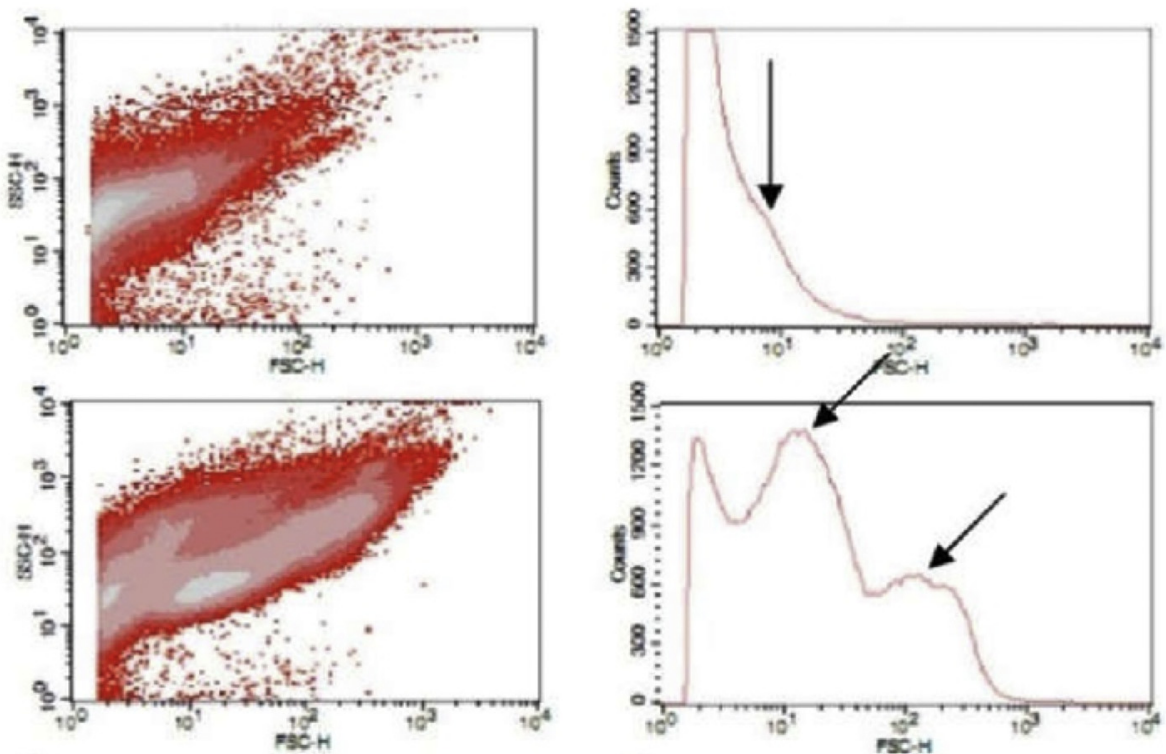

B
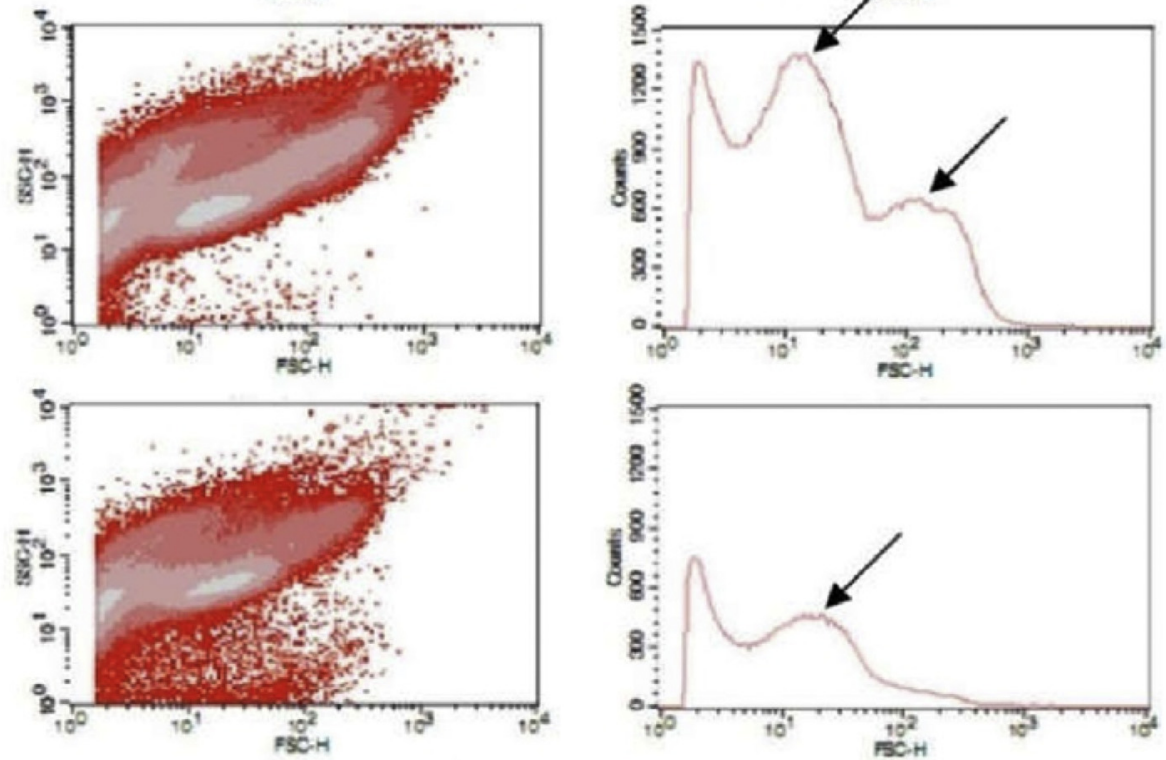

$\mathbf{C}$
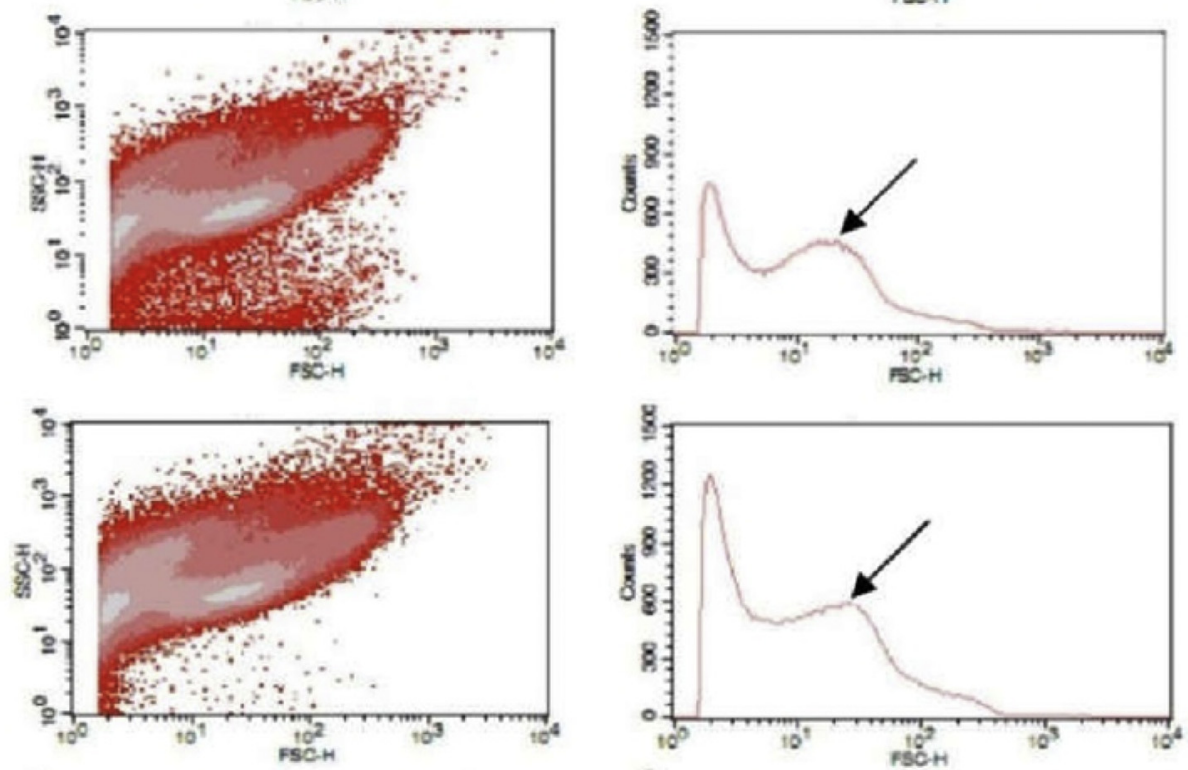

$\mathbf{D}$
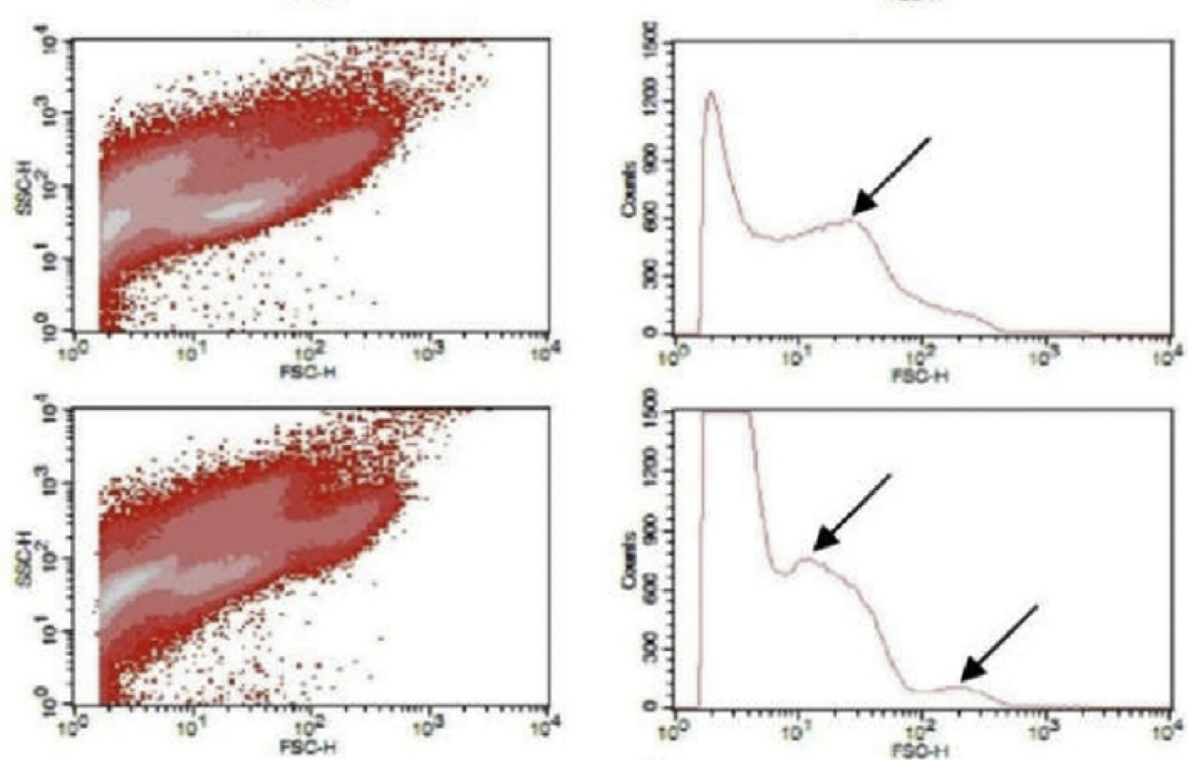

E
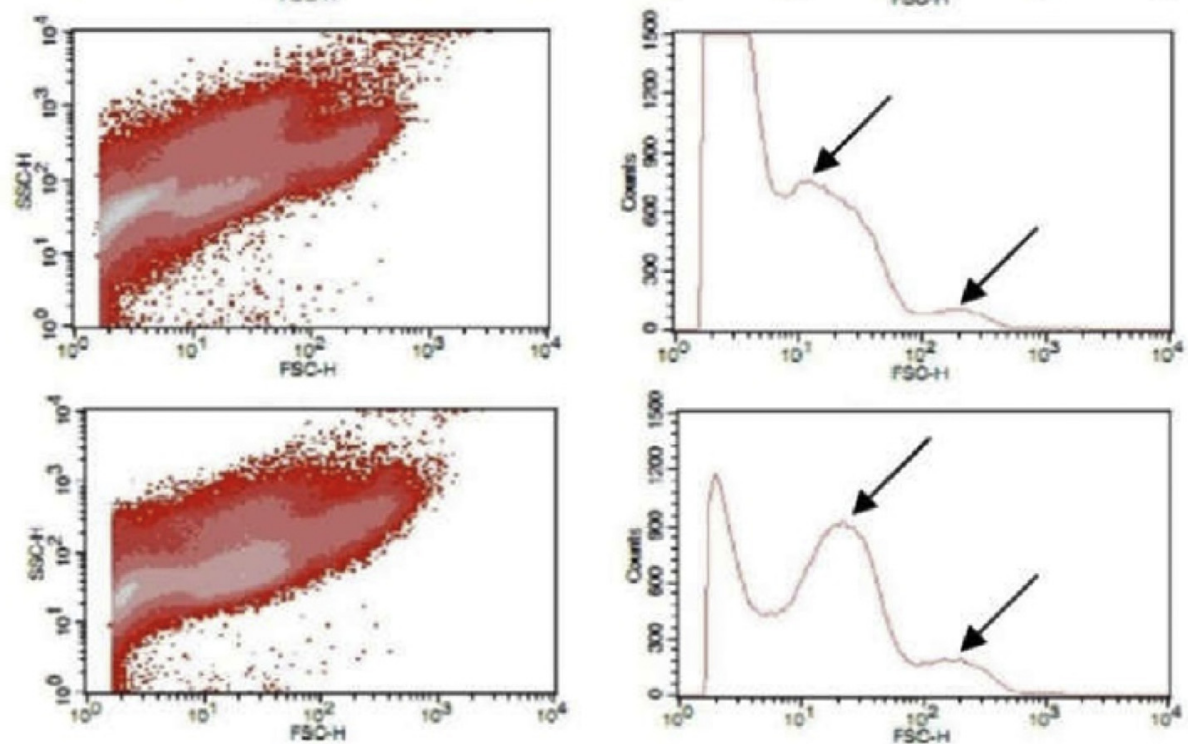

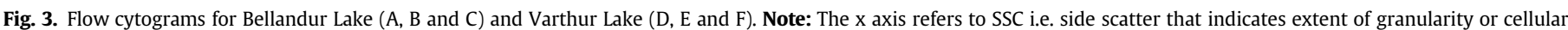

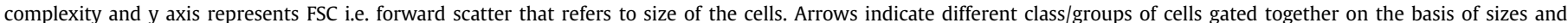
complexities. *A and D represents Inlet; B and E - Middle and C and F - Outlet. 
growth at low P conditions (Kromkamp, 1987). Euglenophyceae members were negatively correlated with total nitrogen (TN) $(\mathrm{r}=-0.64 ; \mathrm{p}<0.05)$ whereas Bacillariophycean members are significantly negative correlated with filterable COD $(\mathrm{r}=-0.58$; $\mathrm{p}<0.05)$ and $\operatorname{BOD}(\mathrm{r}=-0.61 ; \mathrm{p}<0.05)$ and are known to prefer nutrient stress environment. On the other hand, if the total algal count (TAC) is examined, the rank correlation results show negative correlations with filterable COD $(\mathrm{r}=-0.65 ; \mathrm{p}<0.05)$, Amm. $-\mathrm{N}$ $(\mathrm{r}=-0.66 ; \mathrm{p}<0.05)$ and TN $(\mathrm{r}=-0.73 ; \mathrm{p}<0.01)$. Similar results were observed in other studies that showed a bacterial dominance with high concentration of $\mathrm{C}$ and $\mathrm{N}$ and progressive change as the concentration recedes (Veenstra et al., 1995). Total bacterial counts (TBC) were positively correlated with $\mathrm{EC}(\mathrm{r}=-0.66 ; \mathrm{p}<0.05)$, free $\mathrm{CO}_{2}(\mathrm{r}=-0.68 ; \mathrm{p}<0.05), \mathrm{COD}(\mathrm{r}=-0.64 ; \mathrm{p}<0.05)$, filterable COD $(\mathrm{r}=-0.69 ; \mathrm{p}<0.05)$, Amm. $-\mathrm{N}(\mathrm{r}=-0.88 ; \mathrm{p}<0.01)$ and total $\mathrm{N}$ $(\mathrm{r}=-0.87 ; \mathrm{p}<0.01)$ as provided in Table 5 . The bacterial predominance at high COD, $\mathrm{N}$ and electrolyte concentration are in accordance to the studies by Mahapatra et al. (2013b) at high C and $\mathrm{N}$ loads. This shows higher bacterial growth associated with abundance of $\mathrm{C}$ and nutrients with high production of $\mathrm{CO}_{2}$. However, the correlation with EC might be because of higher mineralisation of organics due to faster decomposition with high abundance of bacteria.

Canonical Correspondence Analysis (CCA) showed four distinct regions in the ordinate space characterized by different groups of algae being impacted by specific physicochemical conditions and seasons (Fig. 5). Axis 1 accounted for $60.94 \%$ and axis 2 explained $31.73 \%$ of the total variation, which jointly represents $92.67 \%$ of the total variance. Fig. 5 highlights that parameters such as TP, TN, Amm-N, Turbidity, COD affected the inlets of both lakes (i.e. BM-I,
BPOM-I, VPRM-I, VM-I and VPOM-I), showing the abundance of Chlorophycean members. Only the inlets of Bellandur (BPRM-I) were influenced by filterable COD and BOD, Alkalinity, EC and free $\mathrm{CO}_{2}$, creating conducive environments for higher bacterial growth and abundance and the highest bacterial counts were observed during the pre-monsoon season. However, the regions near the outlets (BM-O and VPOM-O) were significantly influenced by the inorganic parameters (ionic) as $\mathrm{Na}, \mathrm{K}, \mathrm{Ca}$ and $\mathrm{Mg}$, Chlorides and Nitrate- $\mathrm{N}$ where there was predominance of diatom species. Moreover, the outlets (BPOM-O and VM-O) were highly impacted by TDS, pH and temperature pertaining to the growth of Euglenoides.

Bray-Curtis cluster analysis provided the grouping based on spatial similarities of the inlet/outlet seasonality's with different transitions on physico-chemical parameters resulting in changes in biotic activities and communities. The water quality variability in inflows formed four distinct clusters with the outflows especially in the pre-monsoon periods mapping the nutrient concentration with the algal biomass and algal/bacterial abundance (Fig. 6).

Cluster I (87\% similarity) comprised of two sub clusters i.e. subcluster-01 (VM-I and VM-O at 93\% similarity) with VPOM-I (89.5\% similarity) and subcluster-02 (BPRM-O and BPOM-O at $92 \%$ similarity) with VPOM-O (89.75\% similarity). BM-I and BM-O formed cluster two at a similarity of $90 \%$. Cluster III comprise of BPOM-I and BPRM-I with a similarity of $86 \%$ and cluster IV comprised of VPRM-I and VPRM-O at a similarity of $70.25 \%$. The characteristics of VPRM-I and VPRM-O are very different showing significant difference in inlet and outlet characteristics compared to other inflow and outflow characteristics of other seasons as observed by cluster analysis.
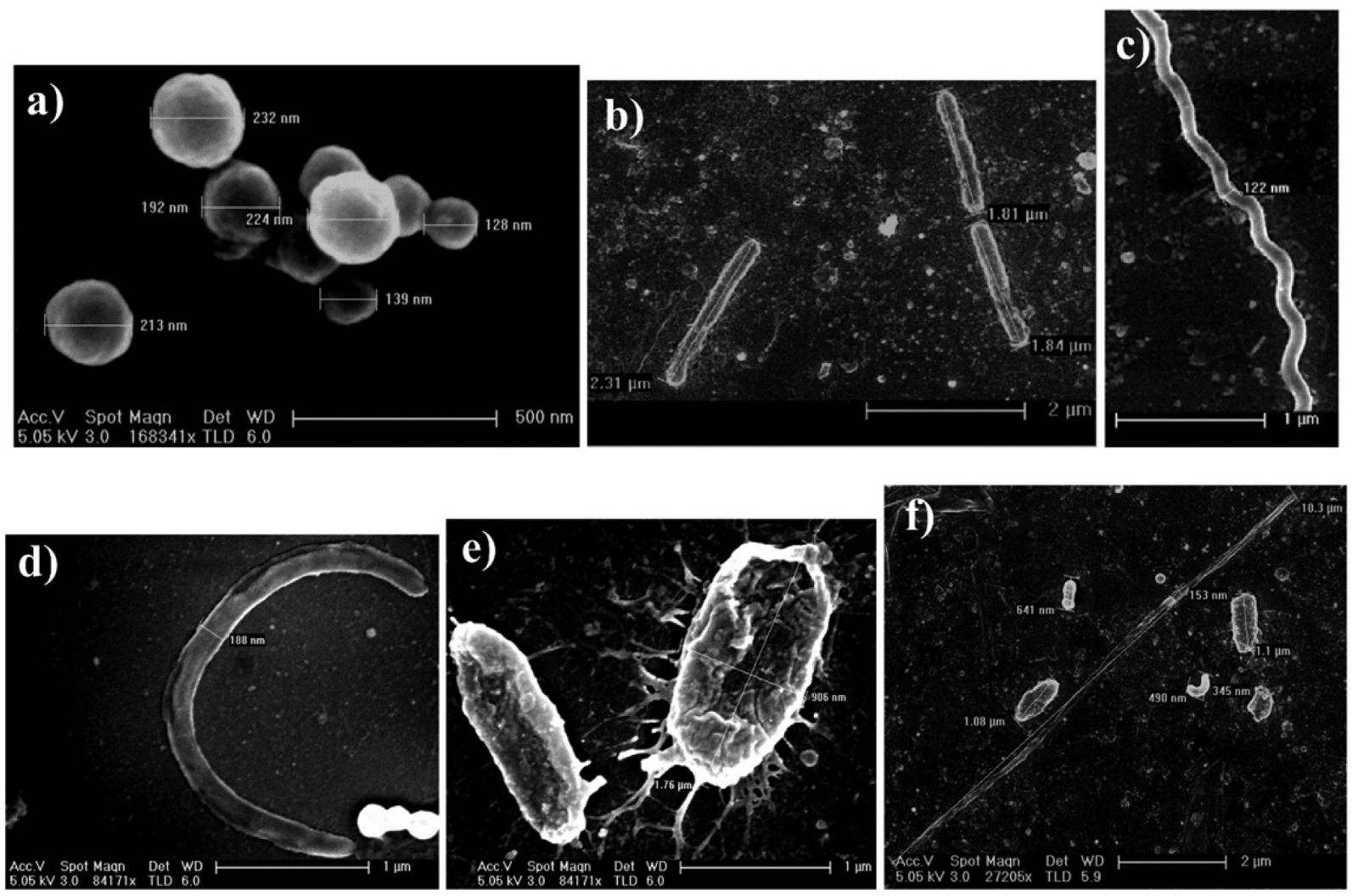

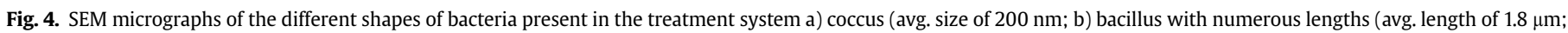

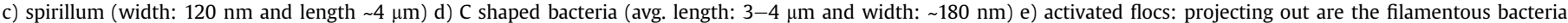

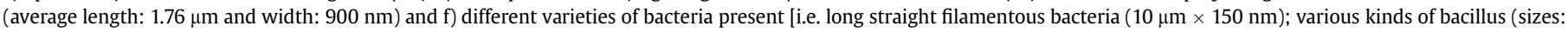
$640 \mathrm{~nm}$ to $1.1 \mu \mathrm{m}$ ); comma shaped bacteria (length: $\sim 500 \mathrm{~nm}$ ). 
Table 5

Spearman's rank correlation between physico-chemical variables and groups of algae growing in the Lakes during the study period.

\begin{tabular}{|c|c|c|c|c|c|c|}
\hline Parameters & Chlorophyceae & Euglenophyceae & Cyanophyceae & Bacillariophyceae & Algal Count & Bacterial Count \\
\hline $\mathrm{pH}$ & -0.53697 & -0.25773 & 0.27434 & -0.30773 & 0.038664 & 0.12281 \\
\hline Temperature & -0.30877 & 0.057471 & 0.13052 & -0.02853 & 0.15762 & 0.055944 \\
\hline EC & -0.24211 & 0.23707 & 0.36686 & -0.10341 & 0.1296 & $0.66434^{*}$ \\
\hline TDS & -0.47018 & 0.38793 & 0.38802 & -0.17829 & 0.32224 & 0.48252 \\
\hline Turbidity & -0.26714 & -0.03238 & -0.11838 & -0.81263 & -0.2807 & 0.43783 \\
\hline DO & -0.17047 & 0.27887 & -0.11838 & 0.37149 & 0.36491 & -0.1366 \\
\hline Free $\mathrm{CO}_{2}$ & -0.18246 & -0.21552 & -0.10935 & -0.14976 & -0.22067 & $0.68531^{*}$ \\
\hline COD & 0.059649 & -0.54598 & -0.40919 & -0.39223 & -0.56743 & $0.64336^{*}$ \\
\hline Filt. COD & 0.082893 & -0.51817 & -0.28901 & $-0.57712^{*}$ & $0.65141^{*}$ & $0.68542^{*}$ \\
\hline BOD & -0.28998 & 0.023389 & -0.0424 & $-0.6126^{*}$ & -0.29123 & 0.55692 \\
\hline Nitrate-N & 0.29474 & -0.12572 & -0.34569 & -0.06062 & -0.16112 & -0.40559 \\
\hline Amm-N & 0.11072 & -0.4192 & -0.23322 & -0.56259 & $-0.65965^{*}$ & $0.87916^{* *}$ \\
\hline $\mathrm{TN}$ & 0.31579 & $-0.63578^{*}$ & -0.5009 & -0.30309 & $-0.7285^{* *}$ & $0.87413^{* *}$ \\
\hline Phosphates & -0.17047 & 0.27887 & -0.11838 & 0.37149 & 0.36491 & -0.1366 \\
\hline $\mathrm{TP}$ & $0.85237^{* *}$ & -0.37962 & $-0.69966^{*}$ & 0.04465 & -0.28772 & 0.010508 \\
\hline Alkalinity & -0.24513 & -0.28185 & 0.073215 & -0.25091 & -0.26775 & -0.02832 \\
\hline Tot. Hardness & 0.44562 & 0.43463 & -0.29631 & -0.11054 & 0.014011 & 0.12587 \\
\hline Chlorides & -0.18375 & 0.46664 & -0.03197 & -0.42373 & 0.13404 & -0.21127 \\
\hline $\mathrm{Na}$ & -0.03158 & 0.5388 & 0.17285 & -0.36014 & 0.20315 & 0.06993 \\
\hline K & -0.01056 & 0.38209 & 0.14336 & -0.29163 & 0.17223 & -0.02456 \\
\hline ORP & 0.035088 & -0.3592 & -0.10935 & 0.032092 & -0.21016 & -0.29371 \\
\hline
\end{tabular}

Bold figures indicate statistically significant.

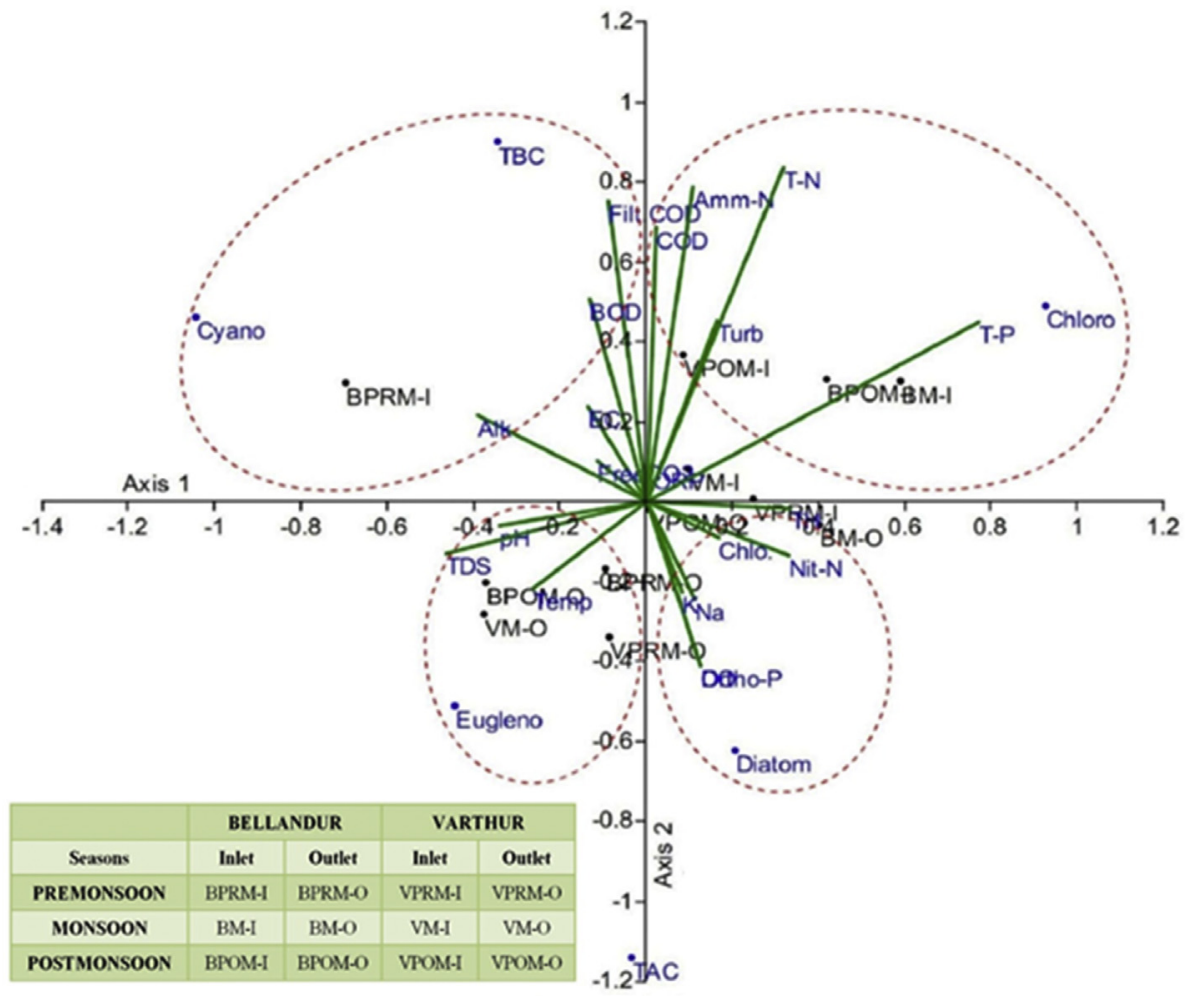

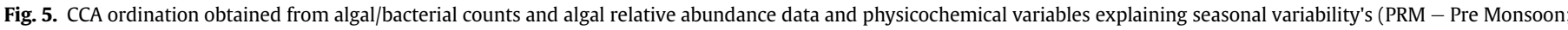

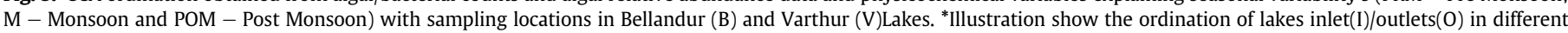

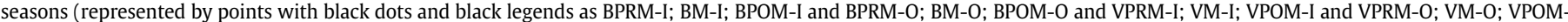

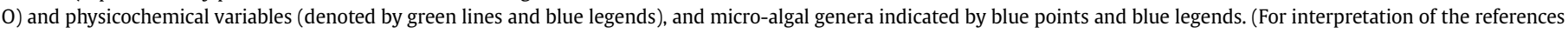
to colour in this figure legend, the reader is referred to the web version of this article.)

\subsection{Nutrient dynamics and budgeting}

The monsoon and the post-monsoon witnessed a significant quantity of BOD removal inferring higher organic matter degradation and uptake. High BOD removal is noticed at locations with open lake surface (without macrophytes cover) with active aerobic environments, which is also evident from high DO concentrations in the Lake. Higher DO levels were due to algal photosynthesises and surface aeration that lowered BOD. Compared to this, thick macrophyte cover during late winter and summer months resulted in poor BOD removal. The lake has been functioning in tandem as an anaerobic-aerobic lagoon imparting a satisfactory treatment in the lake. Therefore, understanding the biotic community succession with the wetland dynamics is essential to arrive at appropriate 


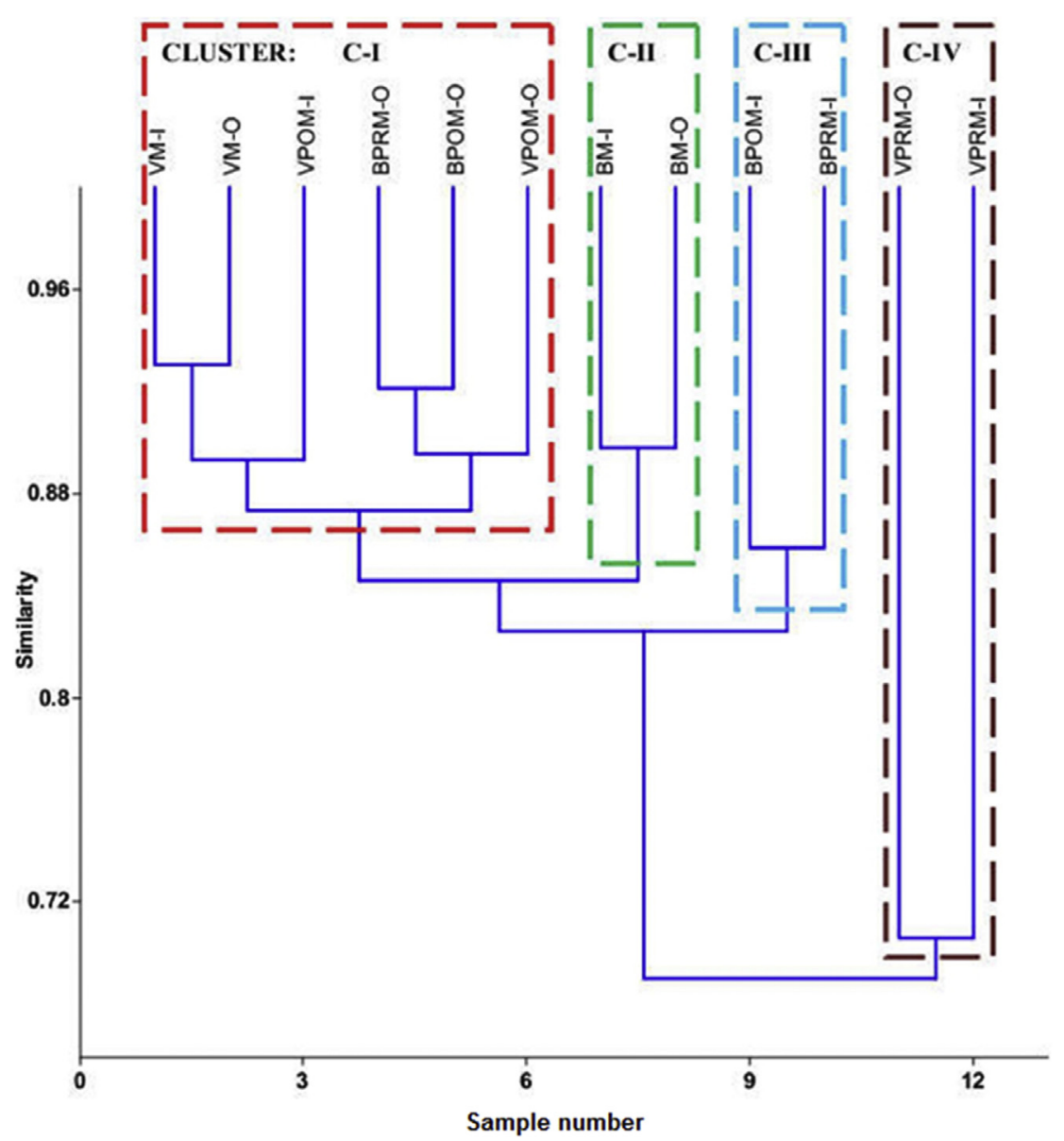

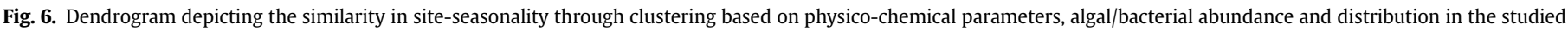
lakes.

treatment strategies and devising location specific constructed wetland that enhances the sustainable water treatment and nutrient bioremediation. This also helps in replicating similar strategies in the emerging cities and towns in India and many developing nations across tropics in addressing the water scarce situations.

Approximately 200 tons of BOD enters the lake daily. Considering higher efficiencies of anaerobic-aerobic lagoon systems, a larger loading and conversion are plausible. De-silting would increase of storage volume, while enhancing the water residence time and treatment. Matching the influent concentrations to the assimilative capacity of the lakes will enhance efficacy of the lake systems with a lively biodiversity that maintains the integrity of the lake. The differential activity of the various communities in the lakes depends upon the nature and type of the wastewater fed into the systems and is mostly driven by various environmental factors such as solar insolation, temperature, pressure, wind speed and rainfall.

About 82 tonnes BOD/d and 78 tonnes, BOD/d enters Bellandur and Varthur Lakes respectively (comparable to typical lagoons). On the other hand, when one considers the maximum potential of the anaerobic-aerobic systems, higher loading rates and higher conversion rates are possible. There is, thus, a need to further examine the potential for higher quality of water at the outlet to enable the recycling and reuse of water in the future upon de-silting and increasing the residence time or reducing the loading. In order to make this more sustainable, the extent of the harvest and the reuse of plant nutrients for the system need to be examined. The contribution of macrophytes and phytoplankton in removing nutrients in these sewage-enriched systems varies with the nature of the effluent and the age of the wetland, in addition to other environmental factors like sunlight, temperature, wind and precipitation.

\subsection{Nutrient-integrated treatment efficiencies}

Crucial treatment parameters are indicative of the remediation performance of urban wetlands. The important factors that influence the treatment ability of the surface water bodies are influent wastewater concentrations, loading rates, microbial community, and the water residence time. The treatment parameters at different phases of treatment determine the degradation of organic matter and transformations, nutrients uptake, and changes in the physic-chemical environment on microbial growth. Concentrations of influent wastewater, volumetric loading, microbial composition, water residence time are the key factors that drive treatment competence. Thus, formulating appropriate treatment efficiency indices are key to the overall efficiency, which helps in evolving future management plans for effective decisions making. Many treatment parameters such as suspended solids, COD, BOD and $\mathrm{NH}_{4}-\mathrm{N}$ removal efficiencies have been considered for assessing the efficiency of the treatment systems (Colmenarejo et al., 2006). Integrated treatment efficiency in the present case has been devised taking into consideration all the crucial parameters from the treatment perspectives that focus on clarity of the water, C, nutrient content with bacterial counts and equal weightages have been 
considered for these parameters. Such Indices help in assessing the treatment levels to cater to an accepted water quality level to be used for any purpose. This helps in deciding additional treatment options for complete treatment of wastewater. Pond based systems in tropics have been used for polishing and maintaining water quality for the end use after treatment and also cleans of bacteria (Jimenez, 2007). Such systems on an average show efficiency close to $90 \%$. In the present study the treatment interacted efficiency is computed as per equation (2).

$\mathrm{TIE}=\left[\mathrm{E}_{\mathrm{TUR}}+\mathrm{E}_{\mathrm{COD}}+\mathrm{E}_{\mathrm{N}}+\mathrm{E}_{\mathrm{P}}+\mathrm{E}_{\mathrm{BAC}}\right] / 5$

where

TIE: Treatment Integrated Efficiency (in percentage),

ETUR: turbidity removal efficiency (in percentage),

ECoD: COD removal efficiency (in percentage),

$\mathbf{E}_{\mathbf{N}}$ : BOD5 removal efficiency (in percentage),

Ep: Nitrogen removal efficiency (in percentage), and

$\mathbf{E}_{\text {BAC: }}$ Phosphorus removal efficiency (in percentage).

TIE values for Bellandur and Varthur Lakes were 64.85 and $63.19 \%$ respectively indicating poor treatment efficiencies due to enormous $C$ and nutrients loading beyond their assimilative capabilities and lower water residence time. This emphasises the need for checking the volume of $C$ and nutrient loads to cope up to their treatment potential. This necessitates a) increasing the oxidative surfaces by regular clearing invasive floating macrophytes (except functionally active floating islands of macrophytes) that hinders sunlight penetration and natural air diffusion in the system, b) provisions for increasing the water residence time by wet dredging for better treatment (which also increases the storage capacity), c) regulating the quality and quantity of wastewater loads by allowing treatments in the upstream of respective wetlands.

\section{Conclusion}

Regular monitoring of water quality (Physico-chemical and biological parameters) at select locations across all seasons in Bellandur and Varthur wetlands, reveal of functioning of wetlands through algal-bacterial treatment as an anaerobic-aerobic stabilisation pond (for two seasons) with a water residence of 5 days and $70 \%$ removal of filterable BOD. Higher proliferation of floating macrophytes reduced the algal photosynthesis and stabilisation of organic matter. Open surfaces facilitate algal growth and thus helps in achieving higher treatment levels appropriate reuse of water in small towns. Urban wetlands in Bangalore have been receiving higher nutrient concentrations from partially or untreated municipal wastewater. This has transformed the physico-chemical integrity and biological entities. Chlorophyceae (Chlorella blooms) were dominant due higher Ammonium-N content and were predominanat inin anoxic-aerobic conditions. Cyanophycean members were mostly observed in the partial anaerobic regions. Seasonal succession is evident with Chlorophycean members dominating the wet periods, while Cyanophycea are dominant during dry periods. Phytoplanktons density correlated with the lake's transparency/turbidity. The CCA analysis showed TP, TN, Turbidity, COD Alkalinity, EC and free $\mathrm{CO}_{2}$ as dominant parameters governing the microflora distribution in the inlets and inorganic parameters (ionic) as $\mathrm{Na}, \mathrm{K}, \mathrm{Ca}$ and $\mathrm{Mg}$, Chlorides and Nitrate-N governing he distribution other algal members in $t$ outlets. The Cluster analysis revealed grouping of sites/seasons with similar nutrient status and showed broadly four different clusters. The present study reveals that Bellandur and Varthur wetlands have been functioning as wastewater fed treatment systems and sustained nutrient enrichments have led to the growth of bacterioplankton, phytoplankton and macrophytes. These two wetlands function differently because of flushing out of the macrophytes during the monsoon and enabling clear water surfaces that functions as high rate algal ponds.

\section{Acknowledgement}

We acknowledge the laboratory facilities at Aquatic Ecology and Molecular Ecology labs in Centre for Ecological Sciences (CES), Biochemistry (BC), Divisional Facilities (Biological Sciences), Institute Nano Initiative (INI, IISc) for their help in Electron microscopy and the Animal Facilities Centre (Flow Cytometry unit) at IISc, for their help during the identification, screening, isolation, enumeration, and characterization of microflora with culture experiments and biochemical composition analysis. The authors also deeply acknowledge the Science and Education Research Board (SERB) (SERB/IUSSTF/2016); Department of Biotechnology (DBT) (IISc/NVJ/ R1011); The Ministry of Science and Technology (DST) (DST/CES/ TVR/1045); Ministry of Environment, Forest and Climate Change (MoEFCC) (DE/CES/TVR/007), Govt. of India and Indian Institute of Science ( $R$ 1011) for providing the financial and infrastructural support.

\section{Appendix A. Supplementary data}

Supplementary data related to this article can be found at https://doi.org/10.1016/j.jenvman.2017.10.054.

\section{References}

Ahmadi, A., Riahi, H., Noori, M., 2005. Studies of the effects of environmental factors on the seasonal change of phytoplankton population in municipal waste water stabilization ponds. Toxicol. Environ. Chem. 87, 543-550. https://doi.org/ $10.1080 / 02772240500315456$.

APHA (American Public Health Association) AWWA WEF, 1998. Standard Methods for Examination of Water and Wastewater, nineteenth ed. Washington DC.

Battle, M., Bender, M.L., Tans, P.P., White, J.W.C., Ellis, J.T., Conway, T., Francey, R.J. 2000. Global carbon sinks and their variability inferred from atmospheric $\mathrm{O}_{2}$ and $\delta^{13} \mathrm{C}$. Science 287, 2467-2470.

Bernal, C.B., Vazquez, G., Quintal, I.B., Bussy, A.L., 2008. Microalgal dynamics in batch reactors for municipal wastewater treatment containing dairy sewage water. Water Air Soil Pollut. 190, 259-270. https://doi.org/10.1007/s11270-0079598-3.

Blackburn, N., Hagström, A., Wikner, J., Cuadros-Hansson, R., Bjoørnsen, P.K., 1998 Rapid Determination of Bacterial Abundance, Biovolume, Morphology, and Growth by Neural Network-based Image Analysis [WWW Document]. URL http://aem.asm.org. (Accessed 20 May 2017).

Carta-Escobar, F., Pereda-Marin, J., Alvarez-Mateos, P., Romero-Guzman, F., DuranBarrantes, M.M., Barriga-Mateos, F., 2014. Aerobic purification of dairy wastewater in continuous regime. Part I: analysis of the biodegradation process in two reactor configurations. Biochem. Eng. J. 21, 183-191.

Chanakya, H.N., Mahapatra, D.M., Sarada, R., Abitha, R., 2013. Algal biofuel production and mitigation potential in India. Miti. Adap. Strat. Global Change 18, $113-136$.

Chanakya, H.N., Mahapatra, D.M., Sarada, R., Chauhan, V.S., Abitha, R., 2012. Sustainability of large-scale algal biofuel production in India. J. IISc 92, 63-98.

Chanakya, H.N., Sharatchandra, H.C., 2008. Nitrogen pool, flows, impact and sustainability issues of human waste management in the city of Bangalore. Curr Sci. 94, 1447-1454.

Colmenarejo, M.F., Rubio, A., Sanchez, E., Vicente, J., Garcia, M.G., Borja, R., 2006 Evaluation of municipal wastewater treatment plants with different technologies at Las Rozas, Madrid (Spain). J. Environ. Manage. 81, 399-404. https:// doi.org/10.1016/j.jenvman.2005.11.007.

Cook, C.D.K., 1996. Aquatic and Wetland Plants of India: a Reference Book and Identification Manual for the Vascular Plants Found in Permanent or Seasonal Fresh Water in the Subcontinent of India South of the Himalayas. Oxford University Press, Oxford, New York.

Desikachary, T.V., 1959. Cyanophyta. Indian Council of Agriculture Research, New Delhi. References - Scientific Research Publish [WWW Document], URL.

Figueiredo, D.R. de, Pereira, M.J., Correia, A., 2010. Seasonal modulation of bacterioplankton community at a temperate eutrophic shallow lake. World J. Microbiol. Biotechnol. 26, 1067-1077. https://doi.org/10.1007/s11274-009-0272-3.

Gasol, J.M., Giorgio, P.A. del, 2000. Using flow cytometry for counting natural planktonic bacteria and understanding the structure of planktonic bacteria 
communities. Sci. Mar. 64, 197-224.

Giorgio, P.A., del, Bird, D.F., Prairie, Y.T., Planas, D., 1996. Flow cytometric determination of bacterial abundance in lake plankton with the green nucleic acid stain SYTO 13. Limnol. Oceanogr. 41, 783-789. https://doi.org/10.4319/ lo.1996.41.4.0783.

Hosetti, B., Frost, S., 1998. A review of the control of biological waste treatment in stabilization ponds. Crit. Rev. Environ. Sci. Technol. 28, 193-218. https://doi.org/ 10.1080/10643389891254205. (S(i43dyn45teexjx455qlt3d2q))/reference/ReferencesPapers.aspx? ReferenceID $=1693451$. (Accessed 20 May 2017).

Iscen, C.F., Emiroglu, O., Ilhan, S., Arslan, N., Yilmaz, V., Ahiska, S., 2008. Application of multivariate statistical techniques in the assessment of surface water quality in Uluabat Lake, Turkey. Environ. Monit. Assess. 144, 269-276. https://doi.org 10.1007/s10661-007-9989-3.

Jimenez, B., 2007. Helminth ova removal from wastewater for agriculture and aquaculture reuse. Water Sci. Technol. 55, 485-493. https://doi.org/10.2166/ wst.2007.046.

Kayombo, S., Mbwette, T.S.A., Mayo, A.W., Katima, J.H.Y., Jørgensen, S.E., 2002 Diurnal cycles of variation of physical-chemical parameters in waste stabilization ponds. Ecol. Eng. 18, 287-291. https://doi.org/10.1016/S0925-8574(01) 00086-6.

Kirkwood, A.E., Nalewajko, C., Fulthorpe, R.R., 2003. Physiological characteristics of cyanobacteria in pulp and paper waste-treatment systems. J. Appl. Phycol. 15 325-335. https://doi.org/10.1023/A:1025181116714.

Kromkamp, J., 1987. Formation and functional significance of storage products in cyanobacteria. N.Z. J. of Mar. Freshwater. Res. 21, 457-465. https://doi.org $10.1080 / 00288330.1987 .9516241$.

Mahapatra, D.M., 2015. Algal Bioprocess Development for Sustainable Wastewater Treatment and Biofuel Production. Ph. D. Thesis. Indian Institute of Science Bangalore, India.

Mahapatra, D.M., Chanakya, H.N., Ramachandra, T.V., 2013a. Euglena sp. as a suitable source of lipids for potential use as biofuel and sustainable wastewater treat ment. J. Appl. Phycol. 25, 855-865.

Mahapatra, D.M., Chanakya, H.N., Ramachandra, T.V., 2011a. Assessment of treatment capabilities of Varthur lake, Bangalore, India. IJETM 14, 84-102. https:// doi.org/10.1504/IJETM.2011.039259.

Mahapatra, D.M., Chanakya, H.N., Ramachandra, T.V., 2011b. C: N ratio of Sediments in a sewage fed Urban Lake. Int. J. Geol. 5, 86-92.

Mahapatra, D.M., Chanakya, H.N., Ramachandra, T.V., 2011c. Role of macrophytes in a sewage fed urban lake. IIOAB 2, 1-9.

Mahapatra, D.M., Chanakya, H.N., Ramachandra, T.V., 2013b. Treatment efficacy of algae-based sewage treatment plants. Environ. Monit. Assess. 185, 7145-7164. https://doi.org/10.1007/s10661-013-3090-x.

Mahapatra, D.M., Chanakya, H.N., Ramachandra, T.V., 2014. Bioremediation an Lipid synthesis of mixotrophic algal consortia in municipal wastewater. Bioresour. Technol. 168, 142-150.

Mahapatra, D.M., Chanakya, H.N., Ramachandra, T.V., 2016. Algae Derived Singlecell Proteins: Economic Cost Analysis and Future Prospects, Book Chapter, Protein Byproducts: Transformation from Environmental Burden into Valueadded Products, first ed. Elsevier, pp. 275-301.

Mahapatra, D.M., Ramachandra, T.V., 2013. Algal biofuel: bountiful lipid from Chlorococcum sp. proliferating in municipal wastewater. Curr. Sci. 105, 47-55.

Marie, D., Le Gall, F., Edern, R., Gourvil, P., Vaulot, D., 2017. Improvement of phytoplankton culture isolation using single cell sorting by flow cytometry. J. Phycol. 53, 271-282. https://doi.org/10.1111/jpy.12495.

Martin-Cereceda, M., Perez-Uz, B., Serrano, S., Guinea, A., 2001. Dynamics of protozoan and metazoan communities in a full scalefull-scale wastewater treatment plant by rotating biological contactors. Microbiol. Res. 156, 225-238. https://doi.org/10.1078/0944-5013-00105.

Martinuzzi, S., Januchowski-Hartley, S.R., Pracheil, B.M., McIntyre, P.B., Plantinga, A.J., Lewis, D.J., Radeloff, V.C., 2014. Threats and opportunities for freshwater conservation under future land use change scenarios in the United States. Global Change Biol. 20, 113-124. https://doi.org/10.1111/gcb.12383.

Naveen, B.P., Mahapatra, D.M., Sitharam, T.G., Sivapullaiah, P.V., Ramachandra, T.V., 2017. Physico-chemical and biological characterization of urban municipa landfill leachate. Environ. Pollut. 220 (Part A), 1-12. https://doi.org/10.1016/ j.envpol.2016.09.002.

Ndungu, J.N., Augustijn, D.C.M., Hulscher, S.J.M.H., Fulanda, B., Kitaka, N., Mathooko, J.M., 2014. A multivariate analysis of water quality in Lake Naivasha, Kenya. Mar. Freshw. Res. 66, 177-186.

Paerl, H.W., Dyble, J., Moisander, P.H., Noble, R.T., Piehler, M.F., Pinckney, J.L., Steppe, T.F., Twomey, L., Valdes, L.M., 2003. Microbial indicators of aquatic ecosystem change: current applications to eutrophication studies. FEMS Microbiol. Ecol. 46, 233-246. https://doi.org/10.1016/S0168-6496(03)00200-9.

Prasanna, M.V., Praveena, S.M., Chidambaram, S., Nagarajan, R., Elayaraja, A., 2012 Evaluation of water quality pollution indices for heavy metal contamination monitoring: a case study from Curtin Lake, Miri City, East Malaysia. Environ.
Earth. Sci. 67, 1987-2001. https://doi.org/10.1007/s12665-012-1639-6.

Prescott, G.W. 1954. How to Know the Fresh-water Algae; an Illustrated Key for Identifying the More Common Fresh-water Algae to Genus, with Hundreds of Species Named Pictured and with Numerous Aids for Their Study. W.C. Brown Co., Dubuque, Iowa.

Prescott, G.W., 1962. Algae of the Western Great Lakes Area, with an Illustrated Key to the Genera of Desmids and Freshwater Diatoms. Rev. ed. ed. W. C. Brown Co., Dubuque, Iowa.

Ramachandra, T.V., 2008. Spatial analysis and characterisation of lentic ecosystems: a case study of Varthur Lake, Bangalore. Int. J. Ecol. Dev. 9, 39-56.

Ramachandra, T.V., Ahalya, N., Payne, M., 2006. Status of Varthur lake: opportunities for restoration and sustainable management. ENVIS Technical Rep. 102, 2006.

Ramachandra, TV., Bhat, S., Mahapatra, D.M., Krishnadas, G., 2012. Impact of indiscriminate disposal of untreated effluents from Thermal power plant on water resources. Indian J. Environ. Protect. 32, 705-718.

Ramachandra, T.V., Mahapatra, D.M., 2015. Science of carbon footprint analysis. Book Chapter. In: The Handbook of Carbon Footprint Assessment. CRC Press, Taylor \& Francis Group, pp. 1-44.

Ramachandra, T.V., Mahapatra, D.M., Bhat, S.P., Joshi, N.V., 2015. Biofuel production along with remediation of sewage water through algae. In: Singh, B., Bauddh, K., Bux, F. (Eds.), Algae and Environmental Sustainability, Developments in Applied Phycology. Springer, India, pp. 33-51. https://doi.org/10.1007/978-81-3222641-3 4 .

Ramachandra, T.V., Mahapatra, D.M., Karthick, B., Gordon, R., 2009. Milking diatoms for sustainable energy: biochemical engineering vs. gasoline secreting diatom solar panels. Ind. Eng. Chem. Res. 48, 8769-8788.

Ramachandra, T.V., Mahapatra, D.M., Samantray, S., Joshi, N.V., 2013. Biofuel from urban wastewater: scope and challenges. Ren. Sus. Energy. Rev. 21, 767-777.

Ramachandra, T.V., Mahapatra, D.M., Vinay, S., Varghese, Asulabha, K.S., Bhat, S.P., Aithal, B.H., 2017. Bellandur and Varthur Lakes Rejuvenation Blueprint, ENVIS Technical Report 116. Environmental Information System, CES, Indian Institute of Science, Bangalore 560012.

Ramachandra, T.V., Vinay, S., Mahapatra, D.M., Varghese, S., Aithal, B.H., 2016. Water Situation in Bengaluru, ENVIS Technical Report 114. Environmental Information System, CES, Indian Institute of Science, Bangalore 560012.

Roche, K.F., 1998. Growth potential of Daphnia magna Straus in the water of dairy waste stabilization ponds. Water Res. 32, 1325-1328. https://doi.org/10.1016/ S0043-1354(97)00272-8.

Shapiro, H.M., 2005. Practical Flow Cytometry, fourth ed. John Wiley \& Sons. ISBN: 9780471722731. http://onlinelibrary.wiley.com/book/10.1002/0471722731.

Singh, J., Behal, A., Singla, N., Joshi, A., Birbian, N., Singh, S., Bali, V., Batra, N., 2009. Metagenomics: concept, methodology, ecological inference and recent advances. Biotechnol. J. 4, 480-494. https://doi.org/10.1002/biot.200800201.

Sukias, J.P.S., Tanner, C.C., Colley, D., Nagels, J.R., J.W., Wolters, R., 2001. Algal Abundance, Organic Matter, and Physicochemical Characteristics of Dairy Farm Facultative Ponds: Implications for Treatment Performance [WWW Document]. NZ J. URL. https://eurekamag.com/research/010/143/010143155.php. (Accessed 20 May 2017).

Tarlan, E., Dilek, F.B., Yetis, U., 2002. Effectiveness of algae in the treatment of a wood-based pulp and paper industry wastewater. Bioresour. Technol. 84, 1-5. https://doi.org/10.1016/S0960-8524(02)00029-9.

Tharavathy, N.C., Hosetti, B.B., Krishnamoorthy, M., 2003. Model waste stabilization ponds for assessing copper toxicity to algae and protozoa. Int. J. Mendel 20 (12), $51-52$.

Timothy, E.F., 2000. Response of marine microbial communities to anthropogenic stress. J. Aquat. Ecosyst. Stress Recover. 7, 75-89. https://doi.org/10.1023/A: 1009971414055

Veenstra, Siemen, Al-Nozaily, Fadhl, Alaerts, Guy, 1995. Purple non-sulfur bacteria and their influence on waste stabilisation pond performance in the Yemen Republic. Water Sci. Technol. 31, 141-149. https://doi.org/10.1016/02731223(95)00501-D.

Veeresh, M., Veeresh, A.V., Huddar, B.D., Hosetti, B.B., 2009. Dynamics of industrial waste stabilization pond treatment process. Environ. Monit. Assess. 169, 55-65. https://doi.org/10.1007/s10661-009-1150-z.

Weatherell, C.A., Elliott, D.J., Fallowfield, H.J., Curtis, T.P., 2003. Variable photosynthetic characteristics in waste stabilisation ponds. Water Sci. Technol. 48, 219-226.

Yang, Y.-H., Zhou, F., Guo, H.-C., Sheng, H., Liu, H., Dao, X., He, C.-J., 2010. Analysis of spatial and temporal water pollution patterns in Lake Dianchi using multivariate statistical methods. Environ. Monit. Assess. 170, 407-416. https://doi.org/ 10.1007/s10661-009-1242-9.

Zhao, Y., Xia, X.H., Yang, Z.F., Wang, F., 2012. Assessment of water quality in Baiyangdian Lake using multivariate statistical techniques. Procedia Environmental Sciences. In: 18th Biennial ISEM Conference on Ecological Modelling for Global Change and Coupled Human and Natural System, vol. 13, pp. 1213-1226. https://doi.org/10.1016/j.proenv.2012.01.115. 